\title{
Structure-Activity Relationship of Cytotoxic Natural Products from Indonesian Marine Sponges
}

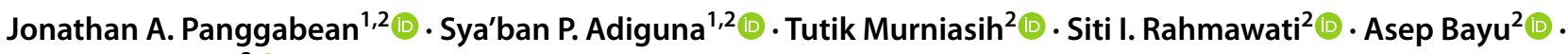 \\ Masteria Y. Putra ${ }^{2}$ (D)
}

Received: 11 July 2021 / Accepted: 15 September 2021 / Published online: 7 January 2022

(c) The Author(s) under exclusive licence to Sociedade Brasileira de Farmacognosia 2022

\begin{abstract}
Indonesian marine natural products have been one of the most promising sources in the race to obtain potential drugs for cancer treatment. One of the primary producers of cytotoxic compounds is sponges. However, there are still limited sources of comprehensive reviews related to the relationship between the structure of isolated compounds and their cytotoxic activity. This review remarks the attempt to provide a preliminary guidance from the perspective of structure-activity relationship and its participation on marine natural products research. This guidance is segregated by the compound's classes and their cytotoxic targets to obtain and organized a reliable summary of inter-study of the isolated compounds and their cytotoxicity. Structure-activity relationship is well-known for its ability to tune the bioactivity of a specific compound, especially on synthetic organic chemistry and in silico study but rarely used on natural product chemistry. The present review is intended to narrow down the endless possibilities of cytotoxicity by giving a predictable structure-activity relationship for active compounds. In addition, bioactive framework leads were selected by uncovering a noticeable structure-activity relationship with the intervention of cytotoxic agents from natural sources, especially Indonesian marine sponge.
\end{abstract}

Keywords Cytotoxicity $\cdot$ Sponges $\cdot$ Structure-activity relationship $\cdot$ Drug development $\cdot$ Cancer treatment

\section{Introduction}

Until 2013, 24,662 new compounds had been reported as marine natural products (MNPs) (Blunt et al. 2015). About $32.4 \%$ of them were isolated from sponges, with a few notable mentions of Indonesian water's contribution. NPs from sponges are used freely here because it is not always clear whether the synthesis occurs in the named organism or the associated symbionts living in the sponge tissue, e.g., cyanobacteria (König et al. 2006). Sponges contain diverse and abundant microbial communities

Asep Bayu

asep.bayu@brin.go.id

$\triangle$ Masteria Y. Putra

masteria.yunovilsa.putra@brin.go.id

1 Department of Chemistry, Faculty of Mathematics and Natural Sciences, Universitas Gadjah Mada, Bulaksumur, Yogyakarta 55281, Indonesia

2 Research Center for Biotechnology, Research Organization for Life Science, National Research and Innovation Agency (BRIN), Jalan Raya Jakarta-Bogor KM. 46, Cibinong, Jawa Barat 16911 Bogor, Indonesia in their tissues, and in many cases, the associated bacterial communities account for over $40 \%$ of the biomass of their hosts, which contribute significantly to the host metabolism via photosynthesis or nitrogen fixation (Taylor et al. 2007).

From 2001 to 2010, the Indonesian marine sponges have established second place among 61 countries on the most abundant producer of specialized metabolites after Japan (Mehbub et al. 2014). Furthermore, the Indonesian marine sponges recently showed their dominance by no less than 130 novel isolated compounds from 2007 to 2020 (Izzati et al. 2021). This supremacy also comes with their various biological activities and chemical diversity. Herein, cytotoxicity or its related anticancer properties is the leading interest for these biological activities (Hanif et al. 2019), followed by antibacterial and other distinct properties, ranging from antiviral properties that serve as potential leads for COVID-19 therapy (Geahchan et al. 2021), enzyme inhibitors for pharmacological application (Ruocco et al. 2017; Yamazaki et al. 2020) to lead compounds for type II diabetes treatment (Abdjul et al. 2017), including potential antiinflammatory agents involved in various diseases such as heart disease, lung disease, bone health, depression, cancer, and anger and aggressive disorders (Kumar and Patravale 2020). Thus, the 
Indonesian marine sponges are an excellent source of bioactive compounds, especially with cytotoxic activity.

Cytotoxicity has emerged from novel compounds and previously known bioactive compounds. In the case of manzamine A (1), it was previously reported to be a potent antibacterial, antifungal, and anti-HIV agent (Peng et al. 2003; Yousaf et al. 2004; Samoylenko et al. 2009), followed by its possibility as a leading drug on Alzheimer's treatment (Rao et al. 2006; Hamann et al. 2007; Peng et al. 2010). Recently, manzamine A (1), isolated from the Indonesian sponge Acanthostrongylophora sp., was also active against cervical cancer (Karan et al. 2020). Sometimes, new biological properties of old compounds are found during screening programs, clinical trials, or practical use of drugs, which becomes a reason for a new indication of therapeutical agents and their alternative sources. For example, the sponge Amphimedon sp., as a source of manzamine type alkaloids against Trypanosoma brucei, the causal agent of human sleeping sickness (Shady et al. 2020). The reverse scenario also shows a promising approach to the previous "old compound vs. new activities" direction. A trimeric xestoquinone-petroquinone B (2) isolated from the Indonesian sponge Petrosia alfiani, for instance, exhibited potent inhibition against ubiquitin-specific protease 7 (USP7) enzyme with comparable $\mathrm{IC}_{50}$ to its dimer, petroquinone $\mathrm{F}(3)$. The activity comes from the unsubstituted position of quinone on compound $\mathbf{3}$ as the reactive region to inhibit USP7 (Scheme 1). However, petroquinone B (2) has fully substituted C-14 and C-15 positions due to its trimeric formation (Tanokashira et al. 2016). This contradictive response of the structure-activity relationship (SAR) opens possibilities on a new mechanism left to be discovered on USP7 inhibition. On a more expansive view, the comparison between manzamine $\mathrm{A}$ and petroquinone B cases establishes the SAR approach's reversible research direction and endless possibilities. structure-activity relationship (QSAR) studies. The fundamental idea of SAR contains three scientific elements, i.e., chemistry, biology, and statistic (McKinney et al. 2000). Its early development emerged from Crum-Brown and Fraser's ideas of the relationship between chemical constitution and physiological action (Brown and Fraser 1868). However, the infinite combination of biological activities and structural features embedded in the endless number of natural compounds is exhaustive on the statistical element. Therefore, the alternative strategy to provide a reliable yet straightforward approach to predicting a compound's bioactivities is to put statistical elements asides and utilize the basic Crum-Brown and Fraser's as a qualitative SAR approach (Choudhuri et al. 2007). Unfortunately, the qualitative tool is still rarely used in the preliminary steps of natural products research even though the early intervention of SAR can predict and generate ideas on the possible bioactivities. In this review, we attempt to provide preliminary guidance of SAR on MNP's cytotoxicity. In particular, the present contribution covers recently isolated compounds from Indonesian marine sponges for their well-known diversity of secondary cytotoxic metabolites and the additional SAR perspective from notable in silico analysis, semisynthetic derivatives, and the study of mechanisms of action for drug discovery.

\section{Search Strategy}

PubMed, Elsevier, American Chemical Society, Google Scholar, MDPI, MarineLit, and SciFinder searches were used to compile the articles containing in the title and abstract such terms as 'cytotoxicity', 'cytotoxic', 'marine sponge', 'Indo-

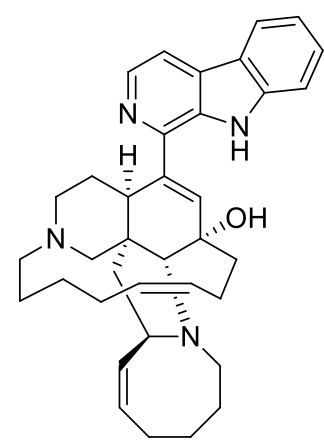

1

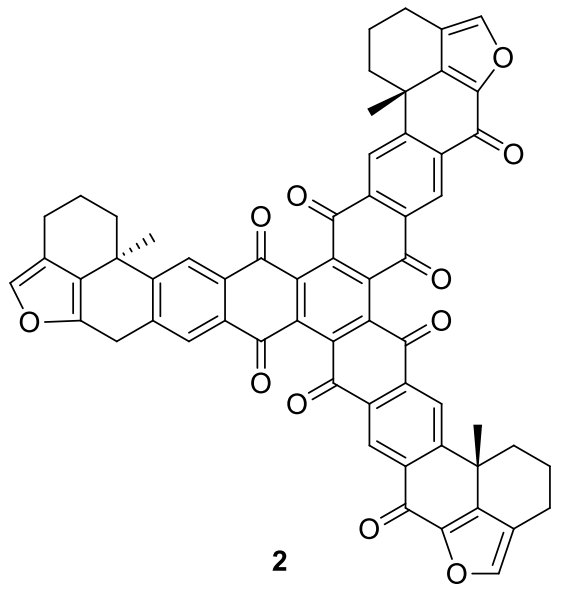<smiles></smiles>

Comprehensive guidance on SAR is needed to dive safely into the endless compound's bioactivities, particularly in the MNPs research. This specific tool is well-known and utilized in organic synthesis and in silico studies, known as quantitative nesia', and 'Indonesian' within the time frame of publication from 2016 to 2021. The searches resulted in 29 articles that contains cytotoxicity assessment from Indonesian marine sponges. Two articles were found to includes cytotoxicity on 


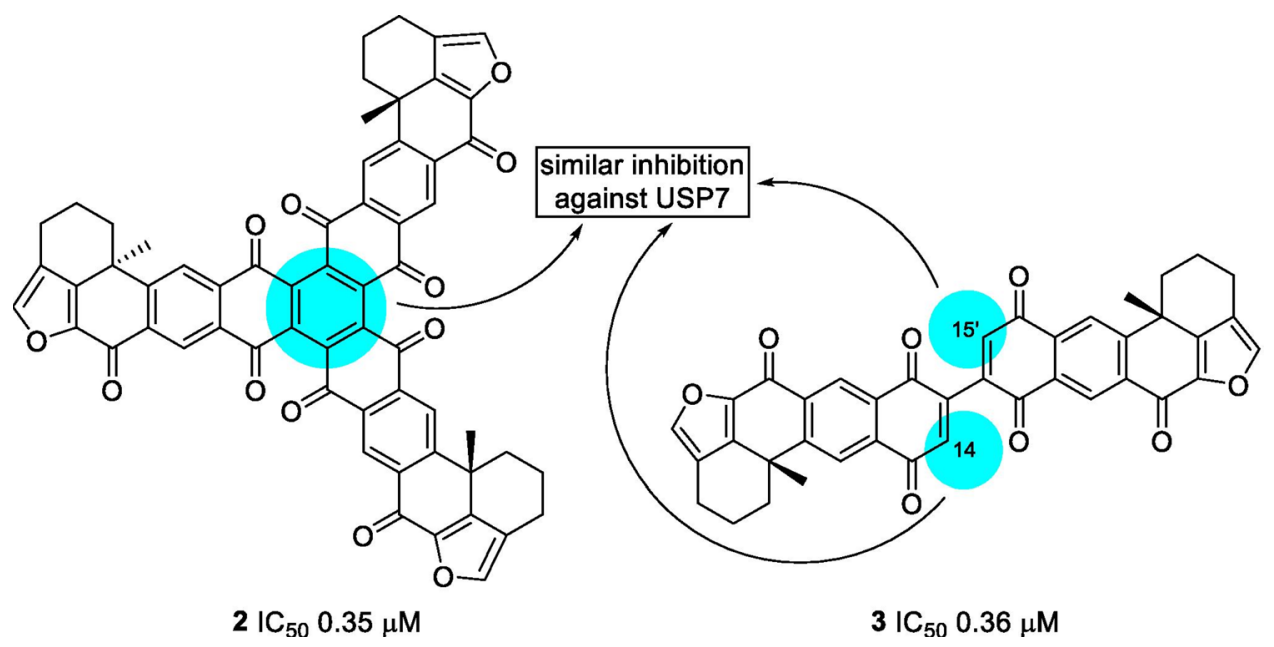

Scheme 1 Contradictive responses of the structure-activity relationship (SAR) open up possibilities on a new mechanism left to be discovered on the inhibition against ubiquitin specific protease 7 (USP7)

marine sponge's extract. Further evaluation on the isolated compounds is conducted by searches from the same sources with respecting keywords on their activities and compound's signature moiety.

\section{Discussion}

\section{Alkaloids}

\section{$\beta$-Carbolines}

Alkaloids are the most well-known cytotoxic compounds of MNPs isolated from sponges (Althagbi et al. 2020) and have established their superiority among other classes of compounds (Izzati et al. 2021). A relatively common moiety found is the $\beta$-carboline (a tricyclic $9 H$-pyrido[3,4-b] indole ring structure), also known as norharman (Cao et al. 2007). This unique structure also bears multiple substituents, followed by vast bioactivity arrays, as manzamine A (1) exhibited before. Previously, numerous reports investigated the effects of $\beta$-carboline alkaloids on the central nervous system (Ayipo et al. 2020), such as their affinity with benzodiazepine receptors (BZRs), 5-HT2A and 5-HT2C receptors (Dai et al. 2018). However, recent interest in these alkaloids has been focused on their potent antitumor (Ahmad et al. 2020), antiviral (Gonzalez et al. 2018), antimicrobial (Arshad et al. 2008) and antiparasitic activities (Ashok et al. enzyme as the trimeric xestoquinone - petroquinone B (2) exhibited potent inhibition with comparable $\mathrm{IC}_{50}$ to its dimer petroquinone $\mathrm{F}$ (3)

2015). In the past two decades, 80 manzamines analogs have been reported, with the possibility of more compounds remains to be characterized and studied for their bioactivity (Yousaf et al. 2004; Hamann et al. 2007). Indonesian marine sponges also contribute to add more members of manzamines and $\beta$-carboline class. In this context, fourteen of them were isolated from Acanthostrongylophora sp., consisting of five new manzamines, four typical manzamines, a dimer, and two imidazole-containing xestomanzamines (Kim et al. 2017).

Kepulauamine A (4; A549: LC $_{50} 4.6 \mu \mathrm{M}$; K562 LC $_{50}$ $7.2 \mu \mathrm{M})$ and manzamine $\mathrm{J} N$-oxide- $\mathrm{HCl}$ (6; A549: $\mathrm{LC}_{50}$ $\left.4.7 \mu \mathrm{M} ; \mathrm{K} 562 \mathrm{LC}_{50} 8.1 \mu \mathrm{M}\right)$ are the two most potent cytotoxic $\beta$-carboline alkaloids against adenocarcinomic human alveolar basal epithelial (A549) cell lines (Kim et al. 2017). For the inhibition of human immortalized myelogenous leukemia (K562) cells, kepulauamine A (4) was also found to be one of the most potent compounds, accompanied with 3,4-dihydromanzamine B $N$-oxide (5; K562: $\mathrm{IC}_{50} 5.2 \mu \mathrm{M}$; A549: $\mathrm{IC}_{50} 5.8 \mu \mathrm{M}$ ) (Kim et al. 2017). Moreover, neokauluamine (7; A549: $\mathrm{IC}_{50} 13 \mu \mathrm{M}$; K562: $\mathrm{IC}_{50} 12 \mu \mathrm{M}$ ) and xestomanzamine B (8; A549: $\mathrm{IC}_{50} 12 \mu \mathrm{M}$; K562 $\mathrm{IC}_{50}$ $13 \mu \mathrm{M})$ exhibited a slightly smaller cytotoxic potential, indicating the importance of appropriate substituent size and the presence of ammonium salt are essential to inhibit A549 cell lines despite the presences of their $\beta$-carboline moiety. 


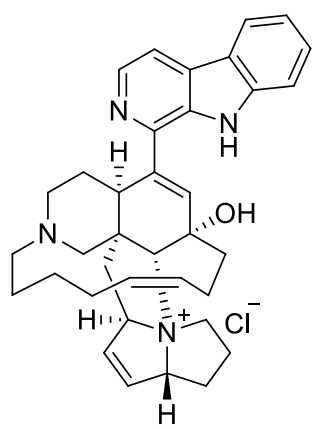

4<smiles>Cn1cncc1C(=O)C1=NCCc2c1[nH]c1ccccc21</smiles>

8

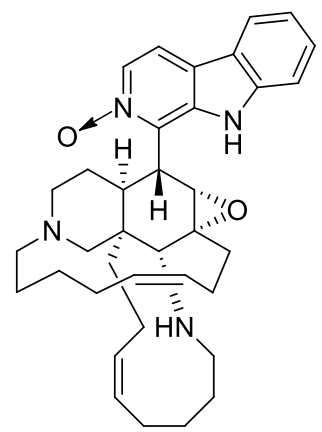

5

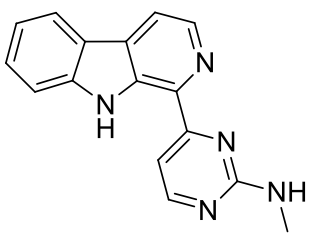

9

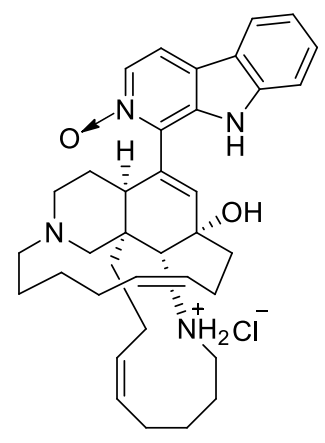

6

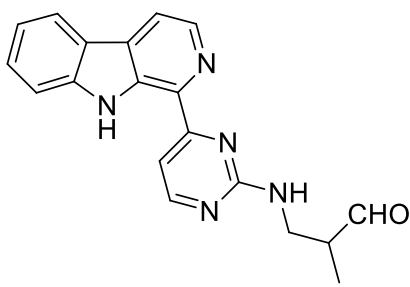

10

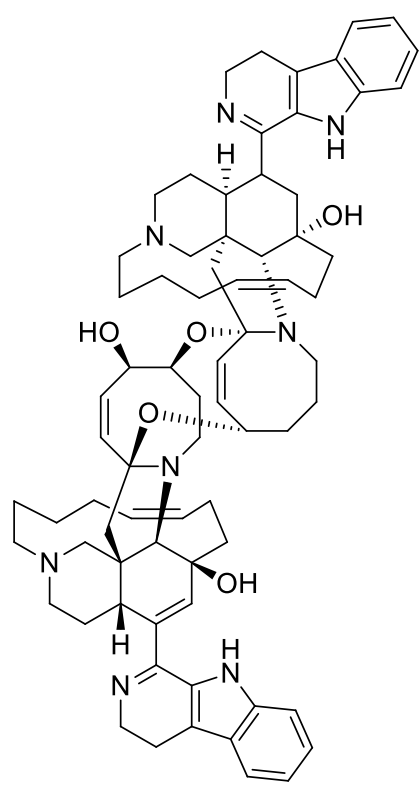

7
Two notable moieties influence the cytotoxicity of compounds (4-6), i.e., the presence of ammonium cation and oxygenated isoquinoline moiety. The influence of $N$-oxide on the $\beta$-carboline core is limited by the group's presence on one compound, as shown by the decreasing cytotoxicity with the removal of oxide interaction on the kepulauamine A (4). For example, the cytotoxicity of 3,4-dihydromanzamine B $\mathrm{N}$-oxide (5) remarks the conjecture of K562's sensitivity to the combination of $N$-oxide and epoxide moiety. This finding is supported by another $N$-oxide dehydromanzamines isolated from a Japanese marine sponge, Amphimedon sp., that showed the most potent inhibition on $\mathrm{KB}$ human epidermoid carcinoma cell lines in comparison with other compounds without the $N$-oxide moiety (Yamada et al. 2009). The heterocyclic $N$-oxide motif has proven to be a very productive emerging scaffold in drug discovery (Mfuh and Larionov 2015). Four modes of action have been proposed for this heterocyclic N-O MNPs: 1) $\mathrm{N}$-oxides can elicit nitric oxide-like effects, acting as a nitric oxide agonist; 2) as bioisosteres for the carbonyl group, making these compounds strong hydrogen bond acceptor with superior enzymatic inhibitory activities; 3) as free radical sources during hypoxic-selective DNA damage; and 4) as nitric oxide donors (Mfuh and Larionov 2015).

Two new $\beta$-carboline alkaloids with a pyrimidine side chain, isolated from Acanthostrongylophora ingens, i.e., ingenine $\mathrm{C}(\mathbf{9})$ and D (10), were cytotoxic against hormonedependent breast carcinoma cell line (MCF7), colon carcinoma cell line (HCT116), and A549 cell lines (Ibrahim and Mohamed 2016). While both compounds showed weak activity for $\mathrm{A} 549$ cell lines, they exhibited potent $\mathrm{IC}_{50}$ values for the two remaining cell lines. Ingenin D (10) was more active against MCF7 $\left(\mathrm{IC}_{50} 2.9 \mu \mathrm{M}\right)$ and $\mathrm{HCT} 116\left(\mathrm{IC}_{50}\right.$ $3.3 \mu \mathrm{M}$ ) than ingenin $\mathrm{C}(9)$ (MCF7: $\mathrm{IC}_{50} 4.3 \mu \mathrm{M}$; HCT116: $\left.\mathrm{IC}_{50} 6.0 \mu \mathrm{M}\right)$. The relationship of the two structures and their cytotoxicity indicates that the 3-aminopropanal extension on ingenin D (10) improves the cytotoxic activity despite the similar methylamine group attached by the pyrimidine group on both compounds.

\section{Pyridinium, Iminium, Pyridine and Pyrrole}

Indonesian marine sponges also provide nitrogenous alkaloid compounds besides the exclusive $\beta$-carboline group (Althagbi et al. 2020). Two of the recent ones are haliclocyclamines C (11) and cyclostellettamines F (12), which were isolated from Haliclona sp. (Maarisit et al. 2017). The bialkylated pyridinium ion compounds 11 and 12 exhibited potential inhibition to vaccinia $\mathrm{H}$-1-related phosphatase (VHR). Haliclocyclamines C (11) was reported to inhibit $28 \%$ of VHR activity at $17 \mu \mathrm{M}$, followed by cyclostellettamines F (12) for $38 \%$ inhibition at $18 \mu \mathrm{M}$. This VHR inhibiton suggests that these compounds are suitable candidates for cancer treatment medication, and for investigating the role of VHR in several cell functions ranging from cell-cycle regulation, DNA damage response, angiogenesis, platelet activation and to mitogen-activated protein kinase signaling (Pavic et al. 2015; Kim et al. 2020). 


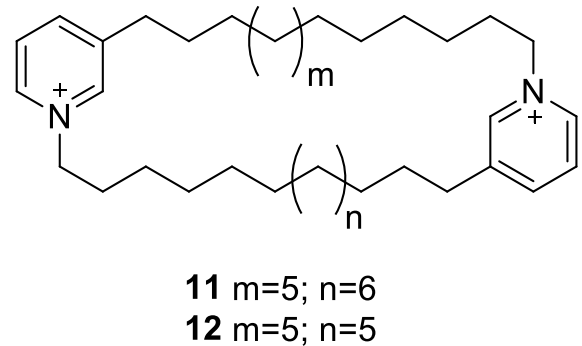

From the perspective of SAR, haliclocyclamines C (11) and cyclostellettamines $F$ (12) show essentials structural features for the VHR binding inhibition, i.e., the two hydrophobic acyl chain moieties and the pyridinium cations. The high hydrophobicity for $\mathbf{1 1}$ and $\mathbf{1 2}$ provides a better cellular penetration (Shi et al. 2007). The binding mode could be proposed through a direct interaction between one of the pyridinium ion and the amino acid Cys124 and/or Try-128 at catalytic loop of the phosphatase (Cys124-Arg130) while the acyl chains would display hydrophobic interactions between each other and lie at the hydrophobic groove near the active site loop. This hypothesis has been demonstrated by in silico modelling through molecular mechanics calculations, energy minimization and analysis of molecular dynamics in water for a dimeric product of the antibiotic RK-682, a tetronic acid derivative and a competitive inhibitor of VHP which was isolated from Streptomyces sp. However, the binding model interaction for RK-682 and its derivatives showed that the inhibitors of VHR need a negatively charged ionic site, the tetronic acid anion with a direct hydrogen bonding interaction with the basic Arg130 residue (Usui et al. 2001).

Chloromethylhalicyclamine B (13; HeLa: $\left.\mathrm{IC}_{50} 6 \mu \mathrm{M}\right)$ has been synthesized from halicylamine B $\left(\mathbf{1 4} ; \mathrm{HeLa}\right.$ : $\mathrm{IC}_{50}$ $12 \mu \mathrm{M})$, which was isolated from Acanthostrongylophora ingens (Esposito et al. 2016). The compounds are different by the presence of the chloromethyl group on $18 \mathrm{~N}$ position, affecting their inhibition activity to protein kinase enzymes CK1. The inhibition of compound $\mathbf{1 3}$ then was examined against various protein kinases, i.e., cyclin-dependent kinase 5 (CDK5/p25), cyclin-dependent kinase 9 and cyclin (TCDK9/cyclin T), CK1 ( $\delta / \varepsilon$ isoforms), cell division control (CDC)-like kinase 1 (CLK1), dual-specificity tyrosine-(Y)phosphorylation regulated kinase 1A (DYRK1A), and glycogen synthase kinase-3 (GSK3). However, compound 13 did not show any activity. The inhibitory potential on CK1 for compound $\mathbf{1 3}$ is supported by a study on a structural discovery of two hydrophobic pockets in the ATP-binding active site of CK1, which could present the most relevant binding pattern consistent with interactions for the highly hydrophobic halogen moiety at the binding pocket 01 , as described by Long et al. (2012), with halogen bonding interactions of the type $\mathrm{R}-\mathrm{X} \cdots \mathrm{Y}-\mathrm{R}^{\prime}$, where the halogen $\mathrm{X}$ acts as a Lewis acid and $\mathrm{Y}$ can be any electron donor moiety on the protein active site (Wilcken et al. 2013), as it could happen with the amino acids Met80, Met82, and Lys38 of CK1 (Rodrigues and de Silva 2017; García-Reyes et al. 2018). Further in silico study shows that chloromethylhalicyclamine B (13) interacts with ATP-binding sites which remarks its potency as a CK1 inhibitor with ATP-competitive manner. The specific development focused on ligand-ATP competition offers a new research direction on CK1 inhibitors with the possibility of spherical compound's class to inhibit CK1 differently than previously known planar compounds (Grieco et al. 2021).

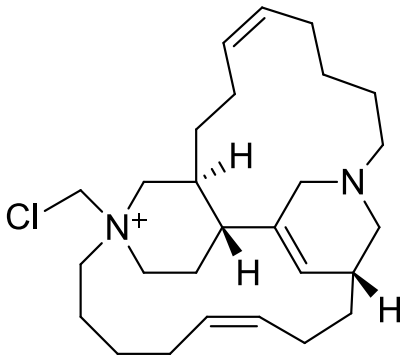

13

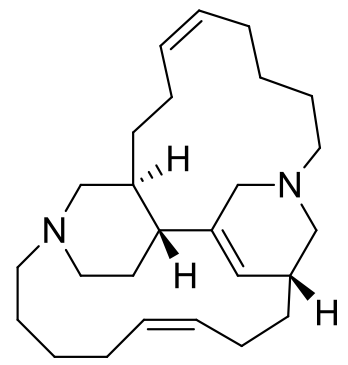

14

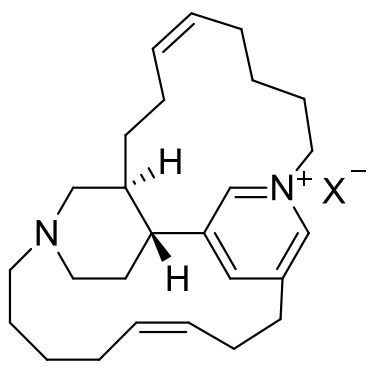

15

Tetradehydrohalicyclamine B (15) was recently isolated compounds from another Acanthostrongylophora ingens together with another encounter on compound 14 (Kato et al. 2019). The absence of halogenated alkyl has been replaced by a pyridinium ion on the opposite piperidine ring of compound 15. Unfortunately, this functional group replacement did not enhance the cytotoxicity against cervical cancer cell lines $\left(\mathrm{HeLa}: \mathrm{IC}_{50}>50 \mu \mathrm{M}\right)$. On the contrary, compound 14 was found to be a cytotoxic agent (HeLa: $\left.\mathrm{IC}_{50} 12 \mu \mathrm{M}\right)$ on the recent assay conducted. Further studies by assessing inhibitory activity against chymotrypsin-like (CT-L), trypsin-like (T-L), and caspase-like (C-L) constitutive proteasome and each respective immuno-proteasome has shown that compound $\mathbf{1 4}$ is more potent on proteasomes inhibition than 15 by CT-L: $\mathrm{IC}_{50} 1.8 \mu \mathrm{M}$; T-L IC $\mathrm{IC}_{50}>15 \mu \mathrm{M}$; C-L: $4.7 \mu \mathrm{M}$ on constitutive proteasome and CT-L: $\mathrm{IC}_{50} 4.1 \mu \mathrm{M}$; 
T-L $\mathrm{IC}_{50}>15 \mu \mathrm{M}$; C-L: $3.1 \mu \mathrm{M}$ for immune-proteasome. Compound 14 inhibit constitutive proteasome by CT-L: $\mathrm{IC}_{50} 0.42 \mu \mathrm{M}$, T-L: $\mathrm{IC}_{50} 6.3 \mu \mathrm{M}$, and C-L IC $500.48 \mu \mathrm{M}$, similar with its inhibition on immune-proteasome by CT-L: $\mathrm{IC}_{50} 0.63 \mu \mathrm{M}$, T-L: $\mathrm{IC}_{50} 8.0 \mu \mathrm{M}$, and C-L: $\mathrm{IC}_{50} 0.44 \mu \mathrm{M}$. The similarity between inhibition of CT-L and C-L of $\mathbf{1 4}$ comes in accordance with previous finding that indicates the increase of compounds specificity on CT-L will reduce its cytotoxicity against HeLa cell line (Screen et al. 2010). Despite the small activity found on the derivatives of $\mathbf{1 4}$, the developed compound on the presented activities provides that the restrain of nitrogenous heterocycle backbone has also limited the compound's biological activities.

Another form of ionic nitrogenous alkaloids has been isolated from Clathria bulbotoxa as crambescidin derivatives (Kasmiati et al. 2018). Compound (20; A431: $\mathrm{IC}_{50} 12 \mathrm{nM}$ ) and (21; A431: $\mathrm{IC}_{50} 48 \mathrm{nM}$ ) show the most significant cytotoxicity against the human epidermoid carcinoma (A431) cell line. The A431 cell line is more prone to $\mathbf{2 0}$ and $\mathbf{2 1}$ than other compounds without long aliphatic chains. However, the presence of a disubstituted acetamide group, as seen on the terminus group of 21, has decreased the compound's cytotoxicity. Despite the shared hydroxide moiety on the terminus group of $\mathbf{2 0}$ and $\mathbf{2 1}$, the sensitivity of A432 cell line favors the carboxylic group on $\mathbf{2 0}$, which is responsible for fourfold of cytotoxicity enhancement. Furthermore, the cytotoxicity ranks linear with the length of carbon chain on the $\mathrm{C} 19$ and $\mathrm{C} 3$ or $\mathrm{C} 4$ for compound 19. The sequence starts with 17 (A431: $\mathrm{IC}_{50} 0.94 \mu \mathrm{M}$ ), as the most active one with two ethyl groups attached, followed by $\mathbf{1 9}$ (A431: $\mathrm{IC}_{50}$ $2.5 \mu \mathrm{M}), \mathbf{1 8}\left(\mathrm{A} 431: \mathrm{IC}_{50} 3.1 \mu \mathrm{M}\right)$, and $\mathbf{1 6}\left(\mathrm{A} 431: \mathrm{IC}_{50} 7 \mu \mathrm{M}\right)$. Despite propyl attachment on $\mathrm{C} 4$, compound 19 exhibited lower cytotoxicity compared to $\mathbf{1 7}$, suggesting that the pair of propyl and ethyl on C19 and C4 attachment has a significant effect. The comparative structures between 16-19 and 20-21 have shown that the aliphatic chain length enhances the cytotoxicity due to the permeability of a compound into the targeted animal cell (Aron et al. 2004). The presence of aliphatic chain on $\mathrm{C} 14$ has been extensively studied to reveals that $\mathbf{2 1}$ induced cell cycle arrest at $\mathrm{G} 2 / \mathrm{M}$ phase which further decrease the cyclin D1, CDK4, and CDK6 expression on the triple negative breast cancer and luminal cancer (Shrestha et al. 2018). The addition of hydroxyl group on $\mathrm{C} 13$ accompanying the sidechain on $\mathrm{C} 14$ were also found to induces the biological activities. Crambescidin 816, which only differs on the addition of hydroxyl group on $\mathrm{C} 13$ from 21, has exhibited a very noticeable higher inhibition (Roel et al. 2016). The utilization of crambescidin derivatives does not only approaches on its biological potential but also on the prospective to provide active compounds through synthetic approach with $\mathbf{1 8}$ as the precursor core (Barbero et al. 2017).

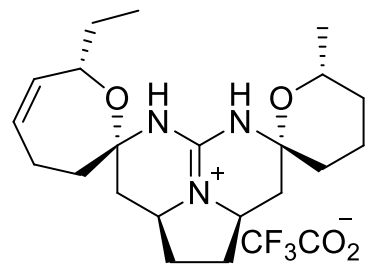

18

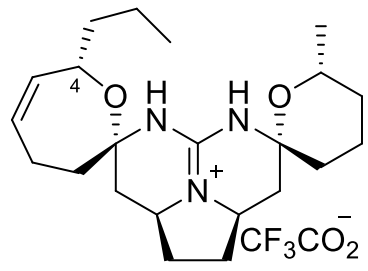

19

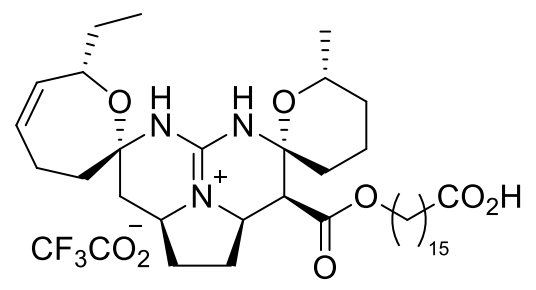

20

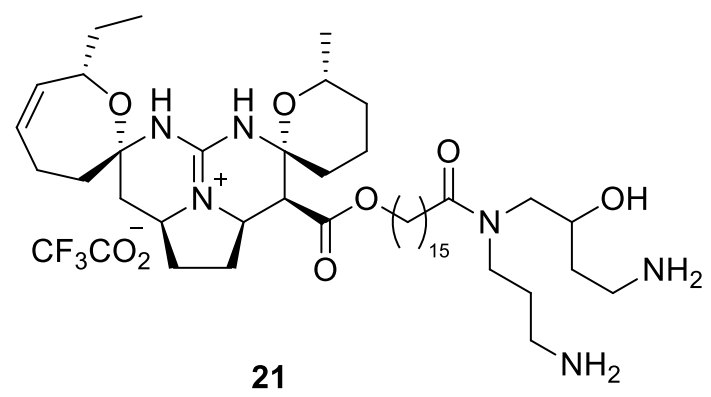

The alkaloids with a wide variety of nitrogen substituents have been studied for their cytotoxic activity. $\mathrm{N}$-methylniphatyne A (22; PANC-1: $\left.\mathrm{IC}_{50} 16 \mu \mathrm{M}\right)$, a member of 3-alkylpyridine alkaloids, is one of the non-ionic nitrogen compounds extracted from Xestospongia sp. (Arai et al. 2016). The small of activity is then evaluated further with a new finding that compound $\mathbf{2 2}$ is cytotoxic against
PANC-1 cell lines on a glucose deficient medium (GDM). In-depth studies on this isolate reveal two synthetic analog, compounds 23 and $\mathbf{2 4}$. Compound $\mathbf{2 4}$ showed an improvement of activity on glucose deficient medium by $8.8 \mu \mathrm{M} \mathrm{IC}_{50}$ compared to compound 23 (PANC-1 GDM: $\mathrm{IC}_{50} 18 \mu \mathrm{M}$ ) and 22 (PANC-1 GDM: $\mathrm{IC}_{50} 16 \mu \mathrm{M}$ ). These results indicate that the relative alkyne's position to 
pyridine and $N$-methoxy- $N$-methyl terminus has slightly enhance cytotoxicity against PANC-1 cell lines.
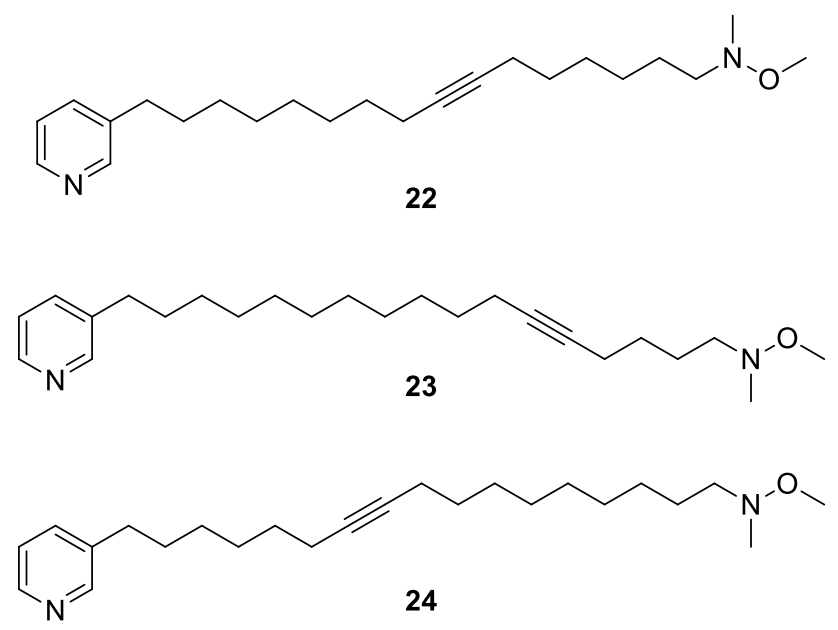

The list of MNPs aiming for PANC-1 cell lines target is extended with another isolation of nitrogenous compound from a large-scale study involving the marine sponge, Zyzzya fuliginosa. The isolation campaign was conducted on four primary Indo-Pacific Zone, including Indonesia, resulting in the isolation of two known compounds, makaluvamine A (25; PANC- 1 : IC $\left._{50} 0.45 \mu \mathrm{M}\right)$ and damirone D (26; PANC-1: IC $_{50} 3.4 \mu \mathrm{M}$ ) (Lin et al. 2017). The cytotoxicity of $\mathbf{2 5}$ is found to be comparable to etoposide (PANC-1: $\mathrm{IC}_{50} 0.39 \mu \mathrm{M}$ ), a semisynthetic glycoside derivative of podophyllotoxin used in combination chemotherapies for treating lung cancer, lymphoma, and leukemia (Zhang et al. 2021b). Despite of the different location, the comparison between compound 25-26 and makaluvamine $\mathrm{J}$ (27) provides the essentials moiety to cytotoxicity against PANC-1 cell lines, which are possibly related with the following structural features: 1) the substituent at B-ring, 2) the presence of iminium ion on C-ring, and 3) the conjugation of fused ABC-ring (Lin et al. 2017). The difference between those three compounds has conjectured the importance of the 4-ethylphenol group as the responsible moiety for almost tenfold increase of cytotoxicity by $0.054 \mu \mathrm{M} \mathrm{IC}_{50}$ for makaluvamine $\mathrm{J}(27)$. Another finding also shows that the presence of diketone moiety attached to B-ring, as seen on 26, decrease its cytotoxic potential by eightfold compared to the aminoketone on $\mathbf{2 5}$. A pattern also emerges from the difference of nitrogen species present on the compound for its linearity with cytotoxicity. The displacement of amine on $\mathbf{2 6}$ with imine as seen on $\mathbf{2 5}$ and iminium ion on $\mathbf{2 7}$ shares the respective sequence of its cytotoxicity. On the specific case of fused $\mathrm{ABC}$ ring moiety, a high-throughput virtual and cell-based screening has provided a makaluvamine $\mathbf{J}(\mathbf{2 7})$ derivative which differs on three moieties, 1) replacement of 4-ethylphenol with 4-chlorobenzyl on B-ring side-chain, 2) tosyl group attachment on A-ring nitrogen, and 3) iminium ion instead of methyl iminium as found on C-ring. This derivative is found to have a potent double-inhibition activity on murine double minute 2 (MDM2) and nuclear factor of activated T cells 1 (NFAT1) oncoproteins which frequently overexpressed on pancreatic cancer (Wang et al. 2018). Another derivative with the presence of thiophen-2-ylmethyl on B-ring and imine on C-ring also shown to be potent on a non-melanoma skin cancer cell (Cowan et al. 2019). These findings further support the significance of conjugation on $\mathrm{ABC}$-ring to be preserved on obtaining potent cytotoxic compounds.<smiles>Cn1cc2c3c1C(=O)C(N)=CC3=NCC2</smiles>

25<smiles></smiles>

26<smiles>C[N+]1=C2C=C(NCCc3ccc(O)cc3)C(=O)c3[nH]cc(c32)CC1</smiles>

27

\section{Brominated Alkaloids}

The brominated alkaloids consist of a wide variety of bromoindole and bromotyrosine derivatives with various bioactivities (Ebada and Proksch 2012). Recently, bromoindole compounds 28-30 were isolated from Oceanapia sp. (LorigRoach et al. 2018). Compound 29 exhibits potent cytotoxicity against PANC-1 cell lines by $1.5 \mu \mathrm{M} \mathrm{IC}_{50}$. However, the accompanied compound $\mathbf{2 8}$ is shown to be not active despite the structural similarity. This inverse response is related to the loss of the carbonyl moiety on $\mathbf{2 8}$. It is also worth mentioning that from the more in-depth SAR assessment, it is found that 30, a synthetic derivative, shows less activity than the parent compound 29. This relationship indicates the importance of bromo's position on the compound. Another interesting feature of these compounds is the presence of ammonium ion. It is similar to the previously proposed essential moiety to inhibit PANC-1 cell lines (Lin et al. 2017). 


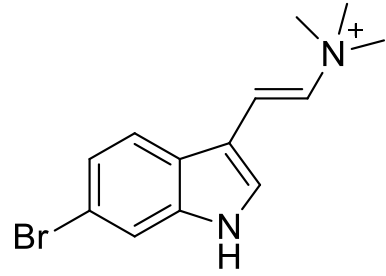

28<smiles>[R]c1cc2[nH]cc(C(=O)C[N+](C)(C)C)c2cc1[R2]</smiles>

$29 \mathrm{R}_{1}=\mathrm{Br} ; \mathrm{R}_{2}=\mathrm{H}$ $30 \mathrm{R}_{1}=\mathrm{H} ; \mathrm{R}_{2}=\mathrm{Br}$
Another group of brominated alkaloids were isolated from the family Aplysinellidae (Order Verongiida) with seven new bromotyrosine derivatives out of a total of thirteen compounds (Dai et al. 2016). The isolated compounds 31-36 were assayed for their cytotoxicity against various cancer cell lines, i.e., human ovarian cancer (A2780S) with its cisplatin-resistant lines (A2780S-CP5), malignant glioblastoma (U251MG), A549, and MCF7 cell lines. The most potent cytotoxicity was displayed by compound 31 , ranging between 9 to $27 \%$ of growth observed compared to dimethyl<smiles>[R]CCc1ccc(OCCCNC(=O)/C(Cc2cc(Br)c(OC)c(Br)c2O)=N/O)c(Br)c1</smiles>

$31 \mathrm{R}=\mathrm{NH}_{2}$<smiles>[NH2+]C(=[NH2+])N[18O]</smiles><smiles>[R]CCc1cc(Br)c(OCCCNC(=O)C2=NO[C@]3(C=C(Br)C(OC)=C(Br)[C@@H]3O)C2)c(Br)c1</smiles>

$34 \mathrm{R}=\mathrm{NH}_{2}$<smiles></smiles>

Other bromotyrosine derivates, as compound $\mathbf{3 7}$, were isolated from the genus Hexadella and from the association of two sponges Jaspis sp. and Bubaris sp., compound $\mathbf{3 8}$ was obtained (Tarazona et al. 2017). Both compounds exhibited sulfoxide (DMSO) control. On the other hand, compound 32 exhibits a broader range of observed growth (60 to 111\%). The key to the structure-activity relationship for $\mathbf{3 1}$ and $\mathbf{3 2}$ is focused on the different terminus groups of each compound. Compound $\mathbf{3 1}$ with more potent inhibition suggested that the $\mathrm{N}$-terminus group plays a significant role. Guaidino moiety on the edge of compound $\mathbf{3 2}$ is considered responsible for its lower activity. The presence of the $\mathrm{N}$-terminus on compound 34 was found to inhibit control cell lines by only $7 \%$ growth, while it inhibited cancer cell lines growth observed ranging between 14 to $71 \%$. The unwanted cytotoxicity against normal mouse fibroblast (NIH3T3) was also found on $\mathbf{3 5}$ and $\mathbf{3 6}$ by only $25 \%$ and $29 \%$ growth, respectively. This similarity indicates that the isolated ketoxime group is essential for the compound's cytotoxic selectivity on cancer cells (Zhai et al. 2018; Tuccinardi et al. 2013). This selectivity is also shown by compound $\mathbf{3 3}$ with a similar ketoxime group as compound $\mathbf{3 1}$ and $\mathbf{3 2}$. Despite the similarity, compound $\mathbf{3 3}$ was found to be not equally active as $\mathbf{3 1}$ and $\mathbf{3 2}$, suggesting that the combination between the direction of 2,6-dibromoanisole and the addition of dibromo methoxy benzene moiety is also significant for cytotoxicity.<smiles>CNCCCOc1c(Br)cc(OCCCNC(=O)/C(Cc2ccc(O)c(Br)c2)=N/O)cc1Br</smiles>

33<smiles>COC1=C(Br)[C@@H](O)[C@]2(C=C1Br)CC(C(=O)NCCCOc1c(Br)cc(C(=O)O)cc1Br)=NO2</smiles>

36

moderate cytotoxic activity against three human cancer cell lines, i.e., A549, colorectal adenocarcinoma (HT-29), and breast adenocarcinoma (MDA-MB-231). The HT-29 cell line was the most sensitive to both compounds $\mathbf{3 7}$ and $\mathbf{3 8}$ 
by $3.2 \mu \mathrm{M}$ and $1.6 \mu \mathrm{M} \mathrm{IC}_{50}$, respectively. Further studies on synthetic analogs from hydrolysis of $\mathbf{3 8}$ have resulted in the generation of compounds 39 and $\mathbf{4 0}$. However, these derivatives did not show any cytotoxic activity. The remaining part of compound $\mathbf{3 8}$ might be related to its cytotoxicity essential pharmacophores, i.e., the presence of 2,6-dibromoanisole, carbonyl moiety on $\mathrm{C} 11$, and $\mathrm{N}$-methylamine, which represents the distinctive structural features on compounds $\mathbf{3 7}$ and 38. The counter position between $C 9$ carbonyl and 2,6-dibromoanisole is preferred to increase cytotoxicity by twofold, together with carbonyl on $\mathrm{C} 11$ and $\mathrm{N}$-methylamine moiety. The substitution pattern of 2,6-dibromoanisole will need further evaluation, for it might be related to selectivity on different cancer cell lines. The $N$-terminus group discussed on compounds (31-36) also might be a subject of selectivity matters for its replacement with dimethylamine terminus on compounds $\mathbf{3 7}$ and $\mathbf{3 8}$.<smiles>COc1c(Br)cc(C[C@H](C(=O)NCCCOc2c(Br)cc(CCN(C)C)cc2Br)N(C)C)cc1Br</smiles><smiles>COc1c(Br)cc(C[C@H](C(=O)N(C)CC(=O)c2cc(Br)c(OCCCN(C)C)c(Br)c2)N(C)C)cc1Br</smiles>

38<smiles>[R]Oc1c(Br)cc(C[C@H](C(=O)O)N(C)C)cc1Br</smiles><smiles>[R]c1c(Br)cc(O)c(Oc2ccc(Br)cc2Br)c1Br</smiles>

$39 \mathrm{R}=\mathrm{CH}_{3}$ $40 \mathrm{R}=\mathrm{H}$

$41 \mathrm{R}=\mathrm{Br}$

$42 \mathrm{R}=\mathrm{H}$

\section{Polybromo Diphenyl Ether}

Besides bromoindole and bromotyrosine derivates, Indonesian marine sponges also provide polybromo diphenyl ethers compounds. These compounds are enriched with polybromo moiety attached to the phenyl substituent of the compound. The biological effect of these halogenated aromatic compounds seems to be linked to the relative hydrophobicity associated the phenomenon of halogen bonding. Transformation of bromophenols and bromoanisoles to polybrominated dibenzo- $p$-dioxins and hydroxy-bromodiphenyl ethers, as compounds $\mathbf{4 1}$ and $\mathbf{4 2}$, takes place by photochemical, enzymatic and surface-catalyzed reactions. Simple bromophenols with all possible substitutions can be formed by photolysis of bromodiphenyl ethers. The meta-substituted bromophenols distinguish this process from natural formation, which produces exclusively ortho- and para-substituted bromophenols (Bidleman et al. 2019). Compounds 41 and $\mathbf{4 2}$ were isolated from Dysidea sp. (Arai et al. 2017). These bromodiphenyl ethers were found to be active against PANC-1 cell lines in glucose deficient conditions. The isolated compounds were also potent by 2.1 and $3.8 \mu \mathrm{M} \mathrm{IC}_{50}$ for compounds 41 and $\mathbf{4 2}$, respectively. Although the cytotoxicity was not comparable to antimycin $\mathrm{A}\left(0.003 \mu \mathrm{M} \mathrm{IC}_{50}\right)$, compound $\mathbf{4 1}$ was found to strongly inhibit complexes II and III in mitochondria from further examination of its mechanism of action by $0.0064 \mu \mathrm{M}$ and $0.86 \mu \mathrm{M} \mathrm{IC}_{50}$, respectively. This evaluation also explains the cytotoxicity of $\mathbf{4 1}$ on glucose deficient medium by preventing cancer cell adaptation to its medium, making $\mathbf{4 1}$ a promising candidate for a selective anti-proliferative agent.

\section{Terpenes}

\section{Diterpenes}

Terpenoids are among the second most common secondary metabolites isolated from Indonesian marine sponges after alkaloids (Izzati et al. 2021). The dominance is supported by a wide variety of terpenoids provided by the versatility of the biosynthetic pathway originating from the isoprene unit. The versatility includes the possibility of the cyclic and aliphatic compound formation with the addition of unique substituents such as halogens, a wide range of oxygenated substituents, and a wide variety of nitrogen-containing functional groups. Furthermore, as the primary source of terpenoids, marine sponges also have established their role in terpenoid-based drugs by the observed biomedical potential (Gross and König 2006; Gershenzon and Dudareva 2007; Wu et al. 2019).

A group of diterpenes has been isolated from Spongia ceylonensis. These compounds consist of seven newly isolated spongian diterpenes, $15 \alpha, 16$-dimethoxyspongi-13en-19-oic acid, and eight known spongian diterpenes (ElDesoky et al. 2016) as presented on compound (43-49). Compounds $\mathbf{4 3}$ and $\mathbf{4 4}$ show the most potent inhibition for two main activities, which are differentiation of murine macrophage (RAW264) cell lines and tartrate-resistant acid phosphatase (TRAP)-positive formation of multinuclear osteoclast. These inhibitions are result from the compound's ability to decrease receptor activator of nuclear factor- $\mathrm{\kappa B}$ 
ligand (RANKL)-induced osteoclastogenesis (El-Desoky et al. 2016). This activity, unfortunately, was found to be absent for the rest of the isolated compounds. The inhibition of RANKL-induced osteoclastogenesis is proposed to be related to the amide position, as demonstrated by the inactive compound $\mathbf{4 7}$ when compared with the same isopentyl substituted compound $\mathbf{4 4}$. It also supported the comparison between $\mathbf{4 3}$ and $\mathbf{4 6}$ that shares ethylbenzene as a substituent with the same contradictive response. Herein, the alkyl attached to amide carbonyl enhance the bulkier alkyl attached to nitrogen in the $\gamma$-lactam ring, resulting in the activity to decrease in value of $13 \mu \mathrm{M} ; 18 \mu \mathrm{M}$ and $>50 \mu \mathrm{M}$ $\mathrm{IC}_{50}$ for 43,44 and 45 , respectively. It is also worth mentioning that replacing $\gamma$-lactam moiety with a furan or a tetrahydrofuran moiety shown by compounds $\mathbf{4 8}$ and $\mathbf{4 9}$, respectively, did not enhance any activities.

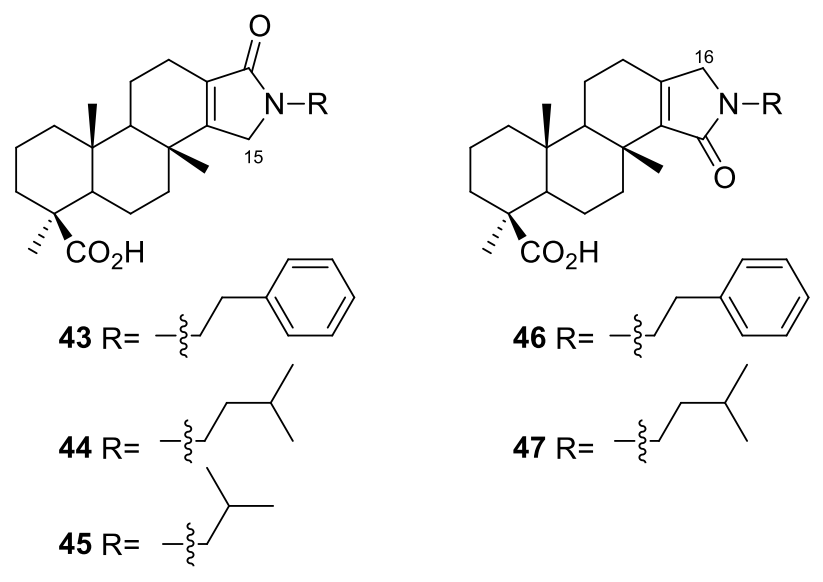<smiles>COC1OC(OC)C2=C1CCC1C2(C)CCC2[C@@]1(C)CCC[C@@]2(C)C(=O)O</smiles>

48<smiles>CC(=O)[C@H]1CCC[C@@]2(C)c3cocc3CCC12</smiles>

49

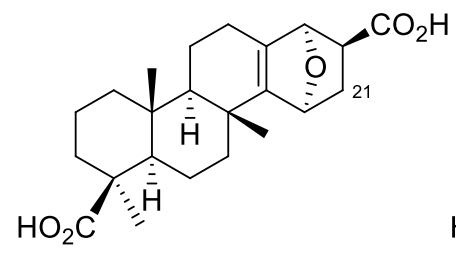

50<smiles>CC12CC[C@H]3[C@H](C(=O)O)CCC[C@]3(C)C1CCC1=C2C2OC1CC2C(=O)O</smiles>

51

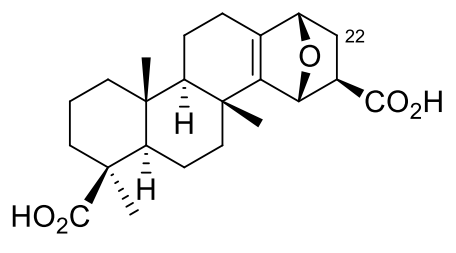

52<smiles>C[C@H]1CCC[C@]2(C)[C@@H]3CCC(C=O)=C[C@]3(C)CC[C@H]12</smiles>

52
Further chemical studies of $S$. ceylonensis regarding the ability to inhibit RANKL-induced osteoclastogenesis, which provides another group of diterpene derivatives 50-52 (El-Desoky et al. 2017a). Compound $\mathbf{5 0}$ exhibited the most significant inhibition of multinuclear osteoclasts formation by $70 \%$ as compared to compound $\mathbf{5 1}$ and $\mathbf{5 2}$ by $28 \%$ and $31 \%$, respectively. It is possible to draw a conjecture that the different activity is related to the conformation of ether bridge linkage and the position of the carboxylic acid substituent. The ether bridge linkage is shown to significantly improve the activity in comparison with the carboxylic acid group, as shown by compound $\mathbf{5 0}$ and compound 51. However, the latter exhibited comparable inhibition to compound $\mathbf{5 2}$ despite the different positions of the carboxylic acid substituent. Besides compound 50-52, S. ceylonensis also provides compound $\mathbf{5 3}$. This compound is a tricyclic diterpene equipped with an unsubstituted ring $\mathrm{C}$ with an aldehyde moiety. The replacement unpredictably showed an inhibition activity against USP7 with an $\mathrm{IC}_{50} 8.2 \mu \mathrm{M}$ (El-Desoky et al. 2017b).

The presence of carbonyl amide moiety is also found in the isolated compound from the same genus, Spongia sp. (Jomori et al. 2019), which provide three new diterpenes and one known diterpenes similar to the compounds $\mathbf{4 3 - 4 7}$. These recently isolated compounds 54-57 were tested for their activity against human prostate cancer (DU145) cell lines. Compound $\mathbf{5 4}$ 
showed the most potent inhibition as compared to the other three by $6.9 \mu \mathrm{M} \mathrm{IC}_{50}$. Compounds $\mathbf{5 5}$ and $\mathbf{5 6}$ were found to be inactive $\left(\mathrm{IC}_{50}>100 \mu \mathrm{M}\right)$, whereas compound $\mathbf{5 7}$ showed inhibition potential with an $\mathrm{IC}_{50} 18.8 \mu \mathrm{M}$. These findings indicate that the orientation of carbonyl moiety is less significant than the substituent attached to nitrogen in the $\gamma$-lactam ring by the inactivity of compounds 55 and $\mathbf{5 6}$. In a broader comparison, the cytotoxicity against DU145 cell lines is more prone to the alkyl substitution on the nitrogen atom than the carbonyl orientation. The orientation of carbonyl was found to have more significance on the previously discussed (RANKL)-induced osteoclastogenesis.<smiles>[R]N1[CH]C2=C(CC[C@@H]3[C@@](C)(C(=O)O)CCC[C@@]23C)[C@@H]1CC</smiles>

$54 \mathrm{R}=\mathrm{H}$ $55 \mathrm{R}=\mathrm{CH}_{3}$<smiles></smiles>

$$
\begin{aligned}
& 56 \mathrm{R}=-\mathrm{CH}_{2} \mathrm{OH} \\
& 57 \mathrm{R}=\mathrm{H}
\end{aligned}
$$

\section{Terpene Quinones}

Another presentation of a wide variety of secondary metabolites from Indonesian marine sponges is exhibited by the isolation of terpenoids with quinone moiety. This compound class belongs to the meroterpenoids compound because of its structure, which combine terpenoids and other compounds from a different biosynthetic pathway (Gomes et al. 2015). The bioactivity of meroterpenes is also varied as their structural variation. For instance, compounds $\mathbf{5 9}$ and $\mathbf{6 0}$ isolated from Dactylospongia elegans were cytotoxic against mouse lymphoma (L5178Y) cell lines $\left(\mathrm{IC}_{50} 1.34 \mu \mathrm{M}\right)$ (Ebada et al. 2017). Their activity is unique because both of them bear a different substituent on quinone moiety and indicate alkyl substituent's insignificance on their cytotoxicity. Compound $\mathbf{5 8}$, which differs from compound $\mathbf{6 0}$ on the position of unsaturated bond and the stereocenter of the neighboring methyl group, was 2-folds less cytotoxic $\left(\mathrm{IC}_{50}\right.$
$2.23 \mu \mathrm{M}$ ) than compound 60 . This finding indicates that the unsaturated bond on the compound's main skeletons is more significant against L5178Y cell lines than alkyl substituents. The comparative structure skeleton of compound (60-62) also exhibits the cytotoxic reduction by $\mathrm{IC}_{50}$ of $1.34 \mu \mathrm{M}, 1.69 \mu \mathrm{M}$, and $6.48 \mu \mathrm{M}$, respectively. This trend indicates the preference for methoxy substituent compares to amine moiety. In addition, the change from primary amine to secondary amine on compounds 61 and 62 is responsible for a significant decrease in cytotoxicity, specify the preference on amine species as the substituent. This finding indicates that the hydrogen presence, which is attached to a nitrogen or oxygen atom, contributes as an essential interaction with the L5178Y cell line.<smiles>[R]C1=CC(=O)C(O)=C(C[C@]2(C)[C@@H](C)CC[C@@H]3C(=C)CCC[C@@H]32)C1=O</smiles><smiles>[R]C1=CC(=O)C(O)=C(C[C@@]2(C)[C@@H]3CCC=C(C)[C@]3(C)CC[C@H]2C)C1=O</smiles>

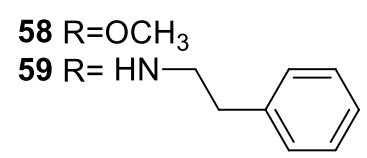

$60 \mathrm{R}=\mathrm{OCH}_{3}$ $61 \mathrm{R}=\mathrm{NH}_{2}$ $62 \mathrm{R}=\mathrm{NHCH}_{2} \mathrm{CO}_{2} \mathrm{H}$<smiles>[R]C1=CC(=O)C(O)=C(C[C@@]2(C)[C@@H]3CCC=C(C)[C@@]3(C)CC[C@H]2C)C1=O</smiles>

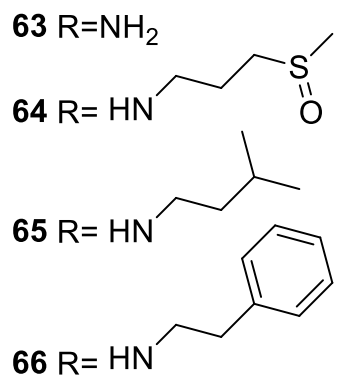

The isolated terpene quinones from Dactylospongia metachromia exhibit a similar structure to previously isolated sesquiterpene quinone derivatives (Ebada et al. 2017). The structural similarity of the isolated compounds also comes following their bioactivity. Compounds 63-67 were found to inhibit cell growth of cervical cancer cell lines expressing cell cycle maker (HeLa/Fucci2) 
by $\mathrm{IC}_{50}$ of $18,16,30,36$, and $13 \mu \mathrm{M}$, respectively (Hitora et al. 2021). The bioactiviy assay then proceeds by cell cycle observation. It is found that compound $\mathbf{6 7}$ did not show disturbance to cell cycle progression, indicating the significant role of benzoquinone and amine moiety to inhibit cell cycles despite the potent cytotoxic activity result. Furthemore, the replacement of sulfinyl with isopropyl moiety in compound $\mathbf{6 5}$ has decreased its cytotoxicity. The significance of sulfinyl moiety, as an important pharmacophore, is also supported by the more potent cytotoxicity of $\mathbf{6 4}$ as compared to the primary amine on compound $\mathbf{6 3}$. The sulfinyl group, possessing a high configurational stability as well as important steric and stereoelectronic differences at 64, represents an intriguing moiety of great importance for biological activity. In turn, sulfoxides are also among various biologically active compounds, including medicines such as omeprazole or sulforaphane (Kiełbasiński et al. 2019).

A wide variety of quinone terpenoids is also represented by the xestoquinones. This iquinone-related secondary metabolites consist of 16 new derivatives (Tanokashira et al. 2016). The compounds comprise trimeric structures, such as compounds 68 and 2, dimeric structures, as compounds $\mathbf{3 , 6 9}$, and 70, and its monomeric units - compound 71, in which all are equipped with notable activity. The compounds were found to inhibit the activity of the USP7 enzyme, which is related to various types of cancer
(Wang et al. 2019; Li and Liu 2020). Compound 71 showed the most potent activity $\left(\mathrm{IC}_{50} 0.13 \mu \mathrm{M}\right)$ followed by compound $\mathbf{3}, \mathbf{6 9}$, and 70 with $\mathrm{IC}_{50} 0.35 ; 0.47$; and $0.49 \mu \mathrm{M}$, respectively. The least active of the top five compounds was the trimeric xestoquinone, compound $68\left(\mathrm{IC}_{50} 0.75 \mu \mathrm{M}\right)$. However, compound 2 exhibited inhibition activity for USP7 on the dimeric region $\left(\mathrm{IC}_{50} 0.36 \mu \mathrm{M}\right)$, comparable with compound 3 . This result suggests that USP7 will react with the unsubstituted position of quinonoid (C-14 and C-15) by any thiol moiety of the enzymatic target (Wang et al. 2011). Besides the previous discussion of the occupancy of C-14 and C-15 positions on compound 2 , the dimeric structure of petroquinones also exhibits a unique chemical feature. A longer bridge or flexible linker between the monomer unit will lower its potential on USP7 inhibition as seen on compound 70. This low activity might be related to both $\mathrm{C} 15$ and $\mathrm{C} 15^{\prime}$ unsubstituted position similar to $\mathrm{C}-14$ and $\mathrm{C}-15$ ' in compound 3 . Besides the unsubsituted $\mathrm{C}-14$ and $\mathrm{C}-15$, the inhibition might be affected by the orientation of the monomer units. However, the orientation on the dimeric 69 shows an enhancement for almost twofold on USP7 inhibition due to a hindered rotation about a single bond as compared with the free rotation in compound 70. This differentiation suggests that further studies are required to investigate the mechanism of USP7 inhibition involving a specific orientation of the monomeric units.

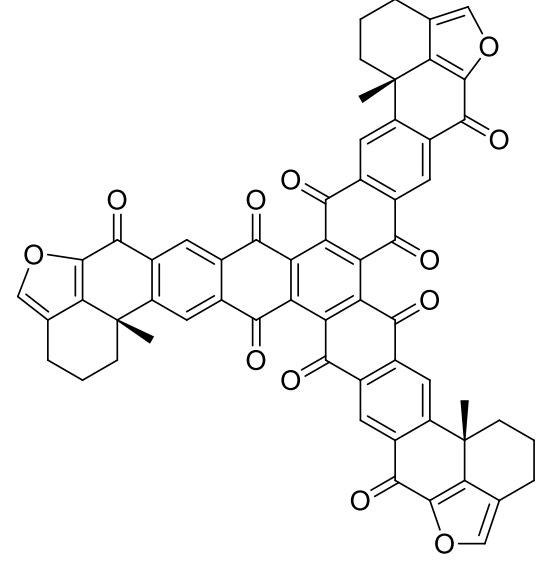

68<smiles>CC1=C(C2=CC(=O)c3cc4c(cc3C2=O)C(=O)c2cc3c(cc2C(=O)C3=O)C2(C)CCCc3coc(c32)C4=O)C(=O)c2occ3c2C13C</smiles>

69<smiles></smiles>

70<smiles>CC12CCCc3coc(c31)C(=O)c1cc3c(cc1C2=O)C(=O)C=NC3=O</smiles>

71 


\section{Carbonyl-Bearing Terpenes}

Besides quinone moiety, MNPs from Indonesian sponges also brought various compounds that bear a carbonyl on a terpene backbone, such as acetylenic acid, galactoside triterpenes, and furanosesterterpenes. One group of the isolated compound belongs to acetylenic derivatives, cinachylenic acids A-D (72-75) (Mokhlesi et al. 2017a). These compounds were isolated from the genus Cinachyrella and show potent activity against L5178Y cell lines. The activity is comparable to a well-known cytotoxic compound, kahalalide $\mathrm{F}\left(\mathrm{IC}_{50} 4.3 \mu \mathrm{M}\right)$, whereas compounds 72-75 showed $\mathrm{IC}_{50} \cong 0.3 \mu \mathrm{M}$. The inhibition was proposed to correlate between unsaturated chains with the permeability of a compound into the targeted cells as presented by quinones (Aron et al. 2004; Kasmiati et al. 2018). On the other hand, cinachylenic acids A-D (72-75) and compounds 58 and 60 share the presence of a methoxy functional group. These findings indicate that the unsaturated chain and the methoxy group equipped the compounds with hydrophobic properties to facilitate cell-permeability.

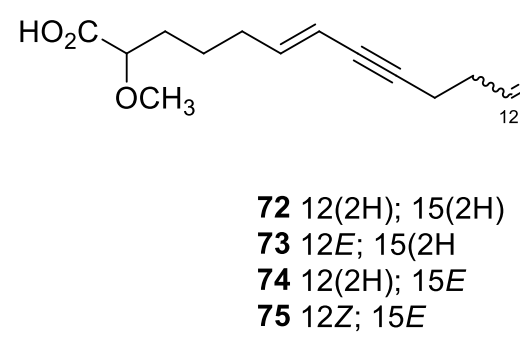

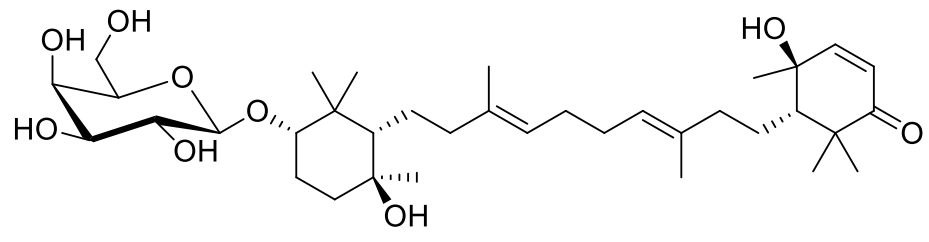

76

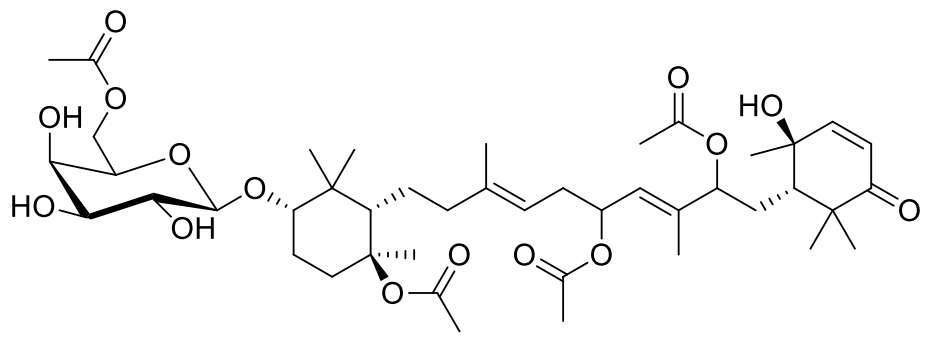

Furthermore, two terpenoids with galactoside moiety, melophluosides A (76) and B (77), were identified from Melophlus sarasinorum (Sadahiro et al. 2020). Cytotoxic assay of the isolated compounds showed that melophulosides A and B have weak sensitivity to HeLa cell lines. The comparative result exhibits an enhancement on the presence of acetoxy group on melophulosides B (77), which could be related to a higher lipophilicity, from hydroxyl and methyl group on melphulosides $\mathrm{A}(\mathbf{7 6})$ with $\mathrm{IC}_{50}$ values of 9.7 and $11.6 \mu \mathrm{M}$, respectively. In addition, meluphulosides A and B show comparable inhibition to the same target as shown by compound $\mathbf{1 4}$ and compound $\mathbf{6 7}$, which belongs to pyridine-bearing alkaloids and a quinone terpenoid, respectively. These pieces of information indicate that pyridine and the enrichment of the carbonyl functional group have an irrelevance effect for the cytotoxicity enhancement and non-selective sensitivity on HeLa cell lines.

The variety of carbonyl-bearing terpenoids also presents a unique structure combination between furan and carbonyl attachment to a terpene skeleton which belongs to furanosesterterpenes compounds. For example, the compounds isolated from Psammocinia sp. (Afifi et al. 2017) show moderate activity against the USP7 enzyme related to the various types of cancer. The inhibition activity is presented as $\mathrm{IC}_{50}$ values of 2.8 ; 4.6 ; 2.7 ; and $3.5 \mu \mathrm{M}$ for compound 78-81, 
respectively. All compounds are cytotoxic with a similar potency. No conclusion could be obtained. It seems that the pharmacophore is related to the unsaturated lactone. Furans<smiles>CC(=[C]CCC1=CC(=O)[C@@H](c2ccoc2)[C@@H]1O)CCCC(C)/C=C1\OC(=O)C(C)=C1O</smiles>

78<smiles>CC1=C(O)/C(=C/C(C)CCC/C(C)=C/CCc2coc(Cc3ccoc3)c2)OC1=O</smiles>

80

Besides the possibility of furan and lactone significance, the similar activity exhibited by compounds $\mathbf{7 8}$ and $\mathbf{8 0}$ also shows the insignificance of methyl addition on the cyclopentenone-furan connection. The preference of significant functional groups then emerges from the terpene backbone. The $E$ and $Z$ on configuration difference are similar to the previously discussed acetylenic acid derivatives compound 72-75, where $E$ configuration on $\mathrm{C} 12$ favors cytotoxicity. The compound 78-81 configuration shows the selective sensitivity of USP7 to the double bond configuration and adds further supports to the significance of monomer orientation of USP7 inhibitor.

\section{Peptides}

Peptides or oligopeptides are well-known bioactive MNPs from sponges, consisting of relatively small number of amino acid residues in either a cyclic or straight formation. This class marked its bioactive debut with the isolation of discodermin A from the sponge Discodermia kiiensis, which bears antibacterial activity (Matsunaga et al. 1984; Ebada and Proksch 2012). A recent review reported that peptides from marine sponges had established their role as an antifungal, anti-inflammatory, and antiviral agents, and their future as important scaffolds for the development of anti-cancer agent (Xie et al. 2020; Zhang et al. 2021a). are non-polar, and the ether oxygen adds a potential for effective hydrogen bonding interactions with target enzymes (Banerjee et al. 2012).<smiles>CC1=C(O)/C(=C/C(C)CC/C=C(\C)CCCc2coc(Cc3ccoc3)c2)OC1=O</smiles>

Indonesian marine sponge is a promising source of cytotoxic peptides since about 20 compounds have been isolated from 1970 to 2017 (Hanif et al. 2019). One of the recent compounds is daedophamide (82) which was isolated from Daedalopelta sp. (Urda et al. 2017). This cyclodepsipeptide consists of multiple amino acids and a "ring" connected by at least one peptide bond, an amide type (Lee et al. 2017). The ester bond of daedophamide (82) is formed between the carbonyl group of pipecolic acid (L-Pip) and the nitrogen of the threonine residue (Thr). The "ring" possessed by $\mathbf{8 2}$ is connected through the amino terminus of threonine and a $\beta$-hydroxy group of 3,4-dimethylglycine (3,4-diMeGln). This novel compound possesses a complex structure and strong activity against four human tumor cell lines, i.e., MDA-MB231, HT-29, A549, and human pancreas carcinoma (PSN-1) cell lines. The inhibition activity of $\mathbf{8 2}$ is strong and comparable to doxorubicin, i.e., $\mathrm{IC}_{50} 0.3$; 0.6 ; 0.4 ; and $0.2 \mu \mathrm{M}$ for daedophamide and $\mathrm{IC}_{50} 0.3 ; 0.2 ; 0.2$; and $0.2 \mu \mathrm{M}$ for doxorubicin, respective, to each tumor cell lines.

Other cyclopeptides isolated from Clathria basilana, i.e., microcionamide $\mathrm{C}(\mathbf{8 3})$, microcionamide $\mathrm{D}(\mathbf{8 4})$, and microcionamide $\mathrm{A}(\mathbf{8 5})$, have a disulfide linkage between two cysteine residues, forming a hexapeptide ring (Mokhlesi et al. 2017b). Compounds 83-85 exhibit strong cytotoxicity against A2780, leukemia (HL-60, Nomo-1, and Jurkat J16), and lymphoma 
(Ramos) cell lines. The inhibition is decreasing from $\mathbf{8 3}, \mathbf{8 4}$, to 85 with only a slight difference between 83 and 84 . The $E$ or $Z$ conformation of 2-phenylethen-1-amine (PEA) on L-Cys ${ }_{1}$ residue is less significant compared to terminal Ile (extension on $\mathrm{R} 2$ ) that favors ethyl rather than methyl with $\mathrm{IC}_{50}$ values of 0.45 ; 0.43 ; and $2.6 \mu \mathrm{M}$ on A2780 cell lines for compound 83-85, respectively. The trends also supported by further assessment that 83-85 are able to activate the caspase-3 protein which leads to apoptosis. However, microcionamide A ( $\mathbf{8 5}$ ) is found to be not active to inhibit autophagy unlike 83 and 84 which bears an ethyl extension on $\mathrm{R} 2$ in comparison with the methyl substituted compound as seen on $\mathbf{8 5}$.

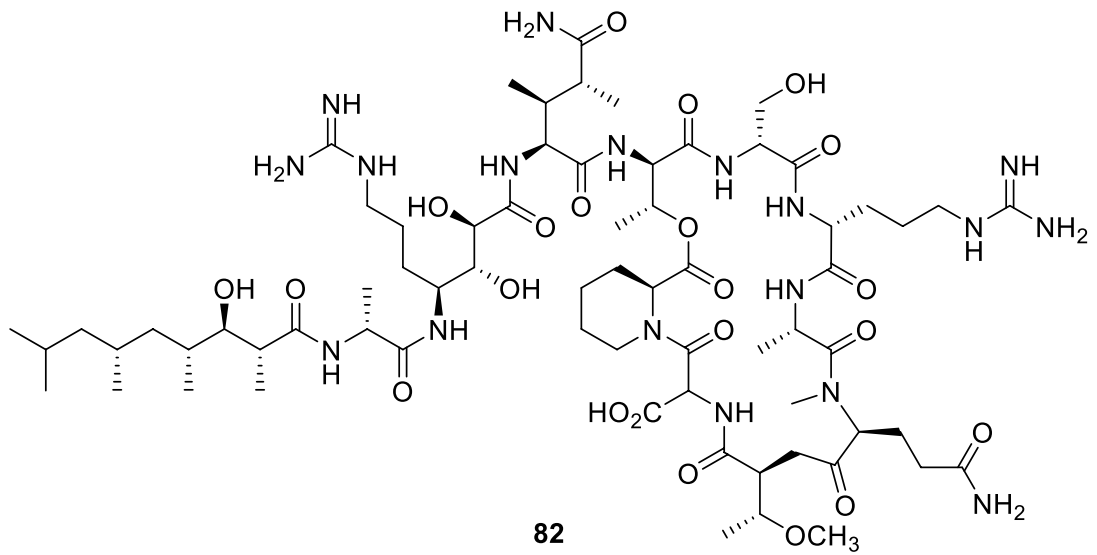<smiles>CCC(C)NC(=O)C(Cc1ccccc1)NC(=O)[C@H](CC)NC(=O)C(Cc1ccccc1)NC(=O)C1CCCN1C(=O)C(Cc1ccc(O)cc1)NC(=O)C(CCC(=O)O)NC(=O)C1CCN(C(=O)C2CCCN2C(=O)C2CCNC2)C1</smiles>

86

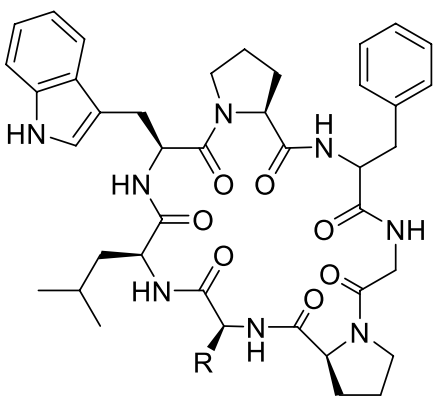

$87 \mathrm{R}=\mathrm{CH}(\mathrm{OH}) \mathrm{CH}_{3}$ $88 \mathrm{R}=\mathrm{CH}_{2} \mathrm{CH}_{2} \mathrm{CO}_{2} \mathrm{H}$

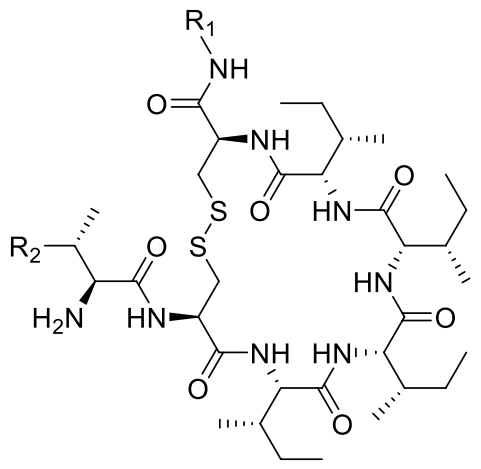

$83 \mathrm{R}_{1}=(E) P E A ; \mathrm{R}_{2}=\mathrm{CH}_{2} \mathrm{CH}_{3}$ $84 \mathrm{R}_{1}=(\mathrm{Z}) \mathrm{PEA} ; \mathrm{R}_{2}=\mathrm{CH}_{2} \mathrm{CH}_{3}$ $85 \mathrm{R}_{1}=(E)$ PEA; $\mathrm{R}_{2}=\mathrm{CH}_{3}$<smiles>C/C=C/c1ccccc1</smiles>

(E) 2-phenylethen-1-amine (PEA)<smiles>C/C=C\c1ccccc1</smiles>

(Z) 2-phenylethen-1-amine (PEA)
As another addition to the list of cyclopeptides, compounds named carteritins A (86), phakellistatin 13 (87), and hymenamides C (88) were isolated from Stylissa carteri (Afifi et al. 2016). The distinctive feature of these cyclopeptides is its enrichment of proline residues as present on $\mathbf{8 6}$ which is parallel with the activity of the compounds against three cancer cell lines, HeLa, HCT116, and RAW264. On the other hand, despite the minor proline moieties present on
87, the compound exhibits notably selective and moderate cytotoxicity against HeLa by $15 \mu \mathrm{M}$ and is considered inactive $(>50 \mu \mathrm{M})$ against HCT116 and RAW264. In terms of selectivity, compound $\mathbf{8 8}$ exhibits potent cytotoxicity against HCT116 by $5.0 \mu \mathrm{M}$ compared to $25 \mu \mathrm{M}$ for HeLa cell lines and considered inactive against RAW264. The similarity of two proline residues on $\mathbf{8 7}$ and $\mathbf{8 8}$ might be the trade for selectivity. The selectivity of $\mathbf{8 7}$ and $\mathbf{8 8}$ might be related to 
the difference in replacement on threonine residue on $\mathbf{8 7}$ to glutamine residue on $\mathbf{8 8}$ added with the cis- and trans-proline conformation between phenylalanine and tryptophan residue.

Jaspis splendens provides cyclic and acyclic cyclodepsipeptide, jasplakinolide (89), (+)-jasplakinolide $\mathrm{Z}_{6}(\mathbf{9 0})$, (+)-jasplakinolide $\mathrm{Z}_{5}(\mathbf{9 1})$, and (+)-jasplakinolide $\mathrm{V}(\mathbf{9 2})$ (Ebada et al. 2019). Some of the isolated compounds showed nanomolar cytotoxicity against L5178 cell lines with an $\mathrm{IC}_{50}<100 \mathrm{nM}$ for compounds $\mathbf{8 9}, \mathbf{9 1}$, and $\mathbf{9 2}$. On the other hand, (+)-jasplakinolide $\mathrm{Z}_{6}(\mathbf{9 0})$ showed a lower cytotoxicity $\left(\mathrm{IC}_{50} 3,200 \mathrm{nM}\right)$. These findings conjecture a relationship between the presence of carboxylic acid terminus on the acyclic form, presented on (+)-jasplakinolide $\mathrm{Z}_{6}(\mathbf{9 0})$ and the registered cytotoxicity in the L5178Y cell line inhibition.

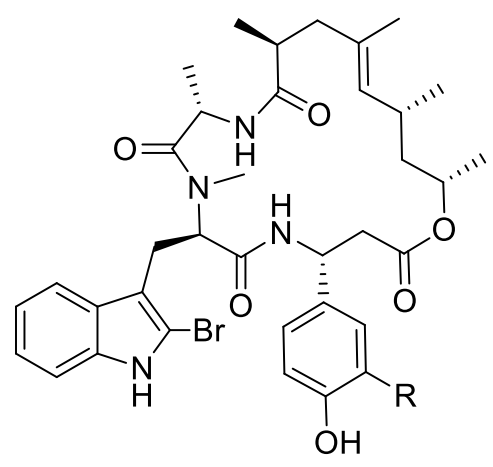

$89 \mathrm{R}=\mathrm{H}$ $92 \mathrm{R}=\mathrm{OH}$<smiles>C/C(=C\[C@H](C)CC(C)O)C[C@H](C)C(=O)N[C@@H](C)C(=O)N(C)[C@H](Cc1c(Br)[nH]c2ccccc12)C(=O)N/C(=C/C(=O)O)c1ccc(O)cc1</smiles>

90<smiles>C/C(=C\[C@H](C)C[C@@H](C)OC(=O)CC(=O)c1ccc(O)c(O)c1)C[C@@H](C)C(=O)N[C@@H](C)C(=O)N(C)[C@H](Cc1c(Br)[nH]c2ccccc12)C(N)=O</smiles>

91

\section{Polyketides}

Some polyketides have also been recently isolated from Indonesian marine sponges. For example, biakamides A-D (93-96) were isolated from the marine sponge Petrosaspongia sp. and exhibited growth inhibition against PANC-1 cell lines with $\mathrm{IC}_{50}$ values of $1.0,4.0,0.5$, and $0.5 \mu \mathrm{M}$ for compounds (93-96), respectively, on glucose deficient medium (Kotoku et al. 2017). Further assessment on their mechanism of action, compound $\mathbf{9 5}$ shows selective inhibition to complex I in the mitochondrial electron transport chain. From the SAR point of view, it is shown that the presence of 3-methoxy-2-butenoyl is more significant than the $E$ or $Z$ conformation. In terms of selectivity, compound 95 did not show inhibition against complex II and III in mitochondria to prevent cancer cell growth in vitro.<smiles>C/C(=C\[C@H](C)C[C@H](C)CC/C(=C/Cl)CCCN(C)C(=O)C[C@@H](C)O)C(=O)N(C)Cc1nccs1</smiles>

93 9E-isomer 94 9Z-isomer<smiles>CO/C(C)=C/C(=O)N(C)CCC/C(=C/Cl)CC[C@H](C)C[C@H](C)/C=C(\C)C(=O)N(C)Cc1nccs1</smiles>

$959 E$-isomer 96 9Z-isomer 


\section{Target-Based Structure-Activity Relationship}

The exposition of SAR on each compound class could be extensively discussed based on their activity. This extended exposition is useful to accommodate the demand for a selective drug from the source and segregated by its targeted cell lines. In this section, we attempt to provide a paper-to-paper comparison to highlight the often-neglected cytotoxicity from one finding that might be a helpful comparison to another in obtaining a comprehensive SAR study.

\section{PANC-1 Cell Line}

The lead compounds with cytotoxic against PANC-1 cell lines, in a nutrient-deprived conditions, are mostly polyketides represented by biakamides, such as 93-96. Compared with polybrominated diphenyl ethers 41-42, most of biakamides showed a decreased cytotoxicity except for biakamides B (96), although both groups contain the halogen group. The position of halogen attached on biakamides was shown to be less significant than the terminus group. The synthetic molecules, compounds 97-100, which are a member of tetrahydroquinolin$2(1 \mathrm{H})$-one derivatives, exhibited a moderate inhibition with $\mathrm{IC}_{50}$ values of 5.2, 4.9, 7.7, and $7.7 \mu \mathrm{M}$, respectively (Shen et al. 2019). Several main moieties are suggested to affect PANC-1 cell line inhibition in a nutrient-deprived conditions. One of them is the presence of the terminal heterocycle moiety, including furan on $\mathbf{9 7}$, thiophene on 98, thiazole on 93-96, or pyridine on 22-24. Thiazole moiety on the heterocycle bearing compound provides the most significant cytotoxicity as presented by the biakamides 93-96. The preference of heterocycle moieties is followed by thiophene on $\mathbf{9 8}$, furan on $\mathbf{9 7}$, and pyridine on 22-24. The significance of heterocycle moiety as a pharmacophore for the cytotoxicity is represented by the lower $\mathrm{IC}_{50}$ on cytotoxicity of compounds $\mathbf{9 9}$ and $\mathbf{1 0 0}$ and exemplified by previous report on synthetic SAR study on the coumarin substituted hydrazide-hydrazone derivatives. The SAR study concludes that the occurrence of the furan terminus group or other heterocycles is enhancing the cytotoxicity against PANC-1 cell lines (Nasr et al. 2014; $\mathrm{Hu}$ et al. 2021). The ability of heterocycles to engage in a wide variety of intermolecular interactions, including hydrogen bond donor/acceptor capability, pistacking interactions, metal coordination bonds as well as van der Waals and hydrophobic forces, allows them to bind in a multitude of ways. In addition, their wide range of ring sizes and structural permutations means heterocycles come in a broad range of shapes and sizes, allowing them to match the equally diverse structural range of enzyme binding pockets on cancer cell lines (Tandon et al. 2019). The second essential moiety for cytotoxicity is the presence of the carbon chain. The preference for more extended alkyl chain moiety is found on three cytotoxic compound groups, which are biakamides 93-96, synthetic tetrahydroquinolin-2(1H)-one derivatives 97-100, and 3-alkylpyridine alkaloids 22-24. The presence of the carbon chain moiety is presumed to correlate with their lipophilicity and the resulting ability for cellular penetration (Aron et al. 2004; Wojcieszak et al. 2018). In addition to carbon chain moiety, the acetamide moiety plays a significant role in cytotoxicity against the PANC-1 cell line on nutrient-deprived conditions. Acetamide's presence on the cytotoxic compounds follows the trends as it is absent on the compound with lower cytotoxicity, i.e., the 3-alkylpyridine alkaloids 22-24 and the polybrominated diphenyl ethers 41-42. Last, the terminus or near terminus hydroxide group is also an essential moiety. The hydroxyl group follows the same trend as the acetamide group on the compounds with a higher cytotoxic potential.

On the other hand, the cytotoxicity assay against PANC-1 cell lines with normal nutrient conditions showed that makaluvamine $\mathrm{J}(\mathbf{2 7})$ and daedophamide (82) had submicromolar value, $\left(\mathrm{IC}_{50} 0.054\right.$ and $0.2 \mu \mathrm{M}$, respectively). The SAR evaluation of the PANC-1 cell line is also provided with synthetic peptides originating from marine cyanobacteria, majusculamide D (101) (Caro-Diaz et al. 2019). The synthetic compound has a sub-nanomolar $\mathrm{IC}_{50}(0.32 \mathrm{nM})$ compare to the sub-micromolar $\mathrm{IC}_{50}$ for daedophamide (82). The remarkable cytotoxicity shown by majusculamide D (101) is obtained from the presence of an alkyl chain, an oxygenated aromatic, and $N$-methylated amides. The significance of $\mathrm{N}$-methylated amide on peptides has been reported to enhance its membrane permeability, proteolytic stability, and solubility which also increases its oral bioavailability (Chatterjee et al. 2008; Northfield et al. 2014; Wu et al. 2021). The conjecture of the three significant moieties on cytotoxicity against PANC-1 brings possible activities from jasplakinolide (89), (+)-jasplakinolide $\mathrm{Z}_{5}(\mathbf{9 1})$, and (+)-jasplakinolide V (92), which bears oxygenated aromatics and alkyl chain. The free secondary-amine will cause the only predicted hindrance on the compound's bromoindole moiety and peptide chain section.

Makaluvamine J (27) also possesses oxygenated aromatic moiety and proceeds to show its submicromolar cytotoxicity despite the neighboring free secondary amine group. In the comparison between makaluvamine $\mathrm{J}$ (27) and makaluvamine A (25), which presented with methylated nitrogen 
and primary amine as a replacement for the oxygenated aromatics, the methylated nitrogen is less significant than oxygenated aromatics moiety for its almost tenfold decrease of cytotoxicity. An overview of cytotoxicity against PANC-1 cell line on normal nutrient and nutrient-deprived conditions shows that the cell line is sensitive to a heterocyclic moiety on the terminus position as shown by majusculamide $\mathrm{D}$ (101), biakamides 93-96, and the synthetic tetrahydroquinolin-2(1H)-one derivatives 97-100.

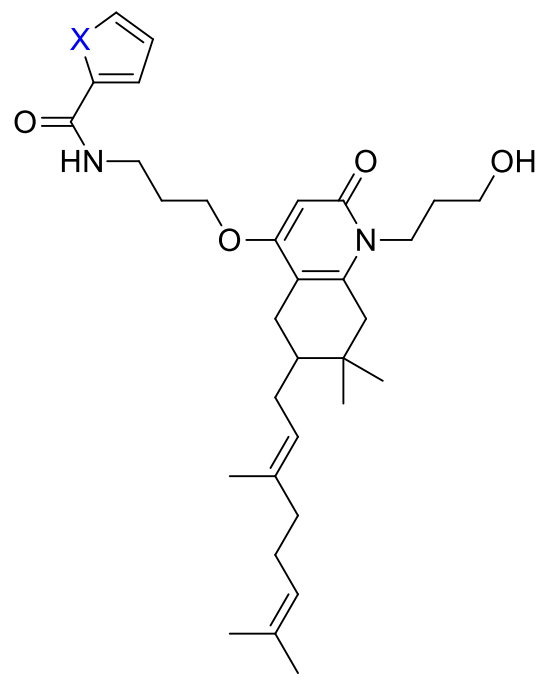

$97 \mathrm{X}=\mathrm{O}$ $98 \times=S$<smiles>COc1ccccc1OC(=O)Nc1cc(=O)n(CCCO)c2c1CC(CC=C(C)C)C(C)(C)C2</smiles>

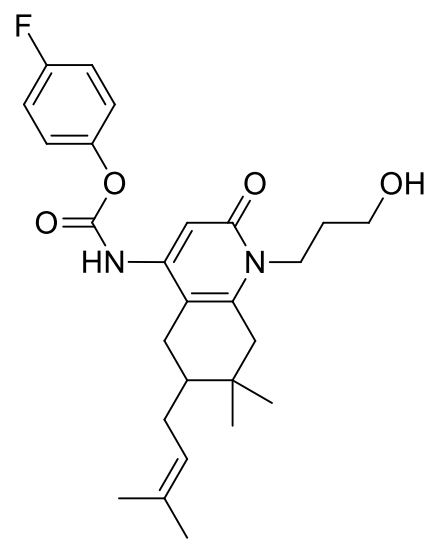

100<smiles>CCCC[C@H](C)C[C@@H](C)C(=O)N(C)[C@H](Cc1ccc(OC)cc1)C(=O)N[C@H](C(=O)N(C)[C@H](C(=O)N1C[C@H](O)C[C@H]1C(=O)N1C(=O)C=C[C@H]1C)C(C)C)[C@H](C)OC(C)=O</smiles>

101

\section{A549 Cell Line}

The lung carcinoma cell lines (A549) emerge as one of the most targeted cell lines from recent studies on cytotoxicity of MNPs from Indonesian sponges. The cytotoxicity against the A549 cell line is led by a peptide, daedophamide (82) and followed by the bromotyrosine derivatives, anomoian B (37) and aplyzanzine B (38) with $\mathrm{IC}_{50}$ values of $0.4,5.1$, and $6.1 \mu \mathrm{M}$, respectively, against $\mathrm{A} 549$ cell lines. Concern also arose for the $\mathrm{LC}_{50}$ value of daedophamide (82). The narrow range between $\mathrm{IC}_{50} 0.4 \mu \mathrm{M}$ and $\mathrm{LC}_{50} 0.7 \mu \mathrm{M}$ should be concerned because it will be affecting the development of daedophamide (82) as a future drug. Recently, Abdel-Rahman and colleagues has conducted a study on cyclohepta[$[b]$ thiophenes derivatives against various cancer cell line. From the study, one compound exhibited a wide range cytotoxicity against colorectal cancer cell line (COLO) $\left(3.07 \mu \mathrm{M} \mathrm{IC}_{50} ; 76.30 \mu \mathrm{M} \mathrm{LC}_{50}\right)$. Furthermore, the studied compound also shows a reduction in tumor growth and stable body weight on animal studies with human xenograft tumor. This study implies the needs of appropriate range between $\mathrm{IC}_{50}$ and $\mathrm{LC}_{50}$ to provide efficacy and safety on the in vivo study (Abdel-Rahman et al. 2020). On the same case, the 
$\mathrm{LC}_{50}$ data shows potential for kepulauamine A (4) and manzamine $\mathrm{J} N$-oxide- $\mathrm{HCl}(\mathbf{6})$, which show a concerning activity by 4.6 and $4.7 \mu \mathrm{M}$, respectively.

In bromotyrosine derivatives, such as psammaplin A monomers (102) and its analogs (103) (Baud et al. 2012; Bao et al. 2021), significance for the cytotoxicity effect of the free ketoxime group over the dimethylamine on $\mathbf{3 7}$ and 38 is evident. Besides the free ketoxime group, the cytotoxicity against the A549 cell line also leans towards a more straightforward structure of bromophenol in comparison to dibromomethoxyphenol moiety as present on $\mathbf{3 1}$ and $\mathbf{3 2}$.<smiles>O=C(CCNC(=O)/C(Cc1ccc(O)c(Br)c1)=N/O)NO</smiles>

102<smiles>O=C(NCCS)/C(Cc1ccc(O)c(Br)c1)=N/O</smiles>

103

\section{Breast Cancer Cell Lines}

A few breast cancer-related cell lines are used on the cytotoxicity assay of recently isolated MNPs from Indonesian marine sponges, including MDA-MB-231, MCF7, and trastuzumab-resistant human epidermal growth factor 2 positive (HER $2+$ ) cell lines. The recently extracted sponge, Aaptos suberitoides, shows a promising inhibition against HER2 + cell lines with $\mathrm{IC}_{50} 12 \mathrm{ppm}$ (Bashari et al. 2021). As the recent studies already reveal the potential cytotoxicity of Indonesian marine sponge, further research on compound isolation will provide remarkable benefits to obtain comprehensive comparison on the isolated compounds.

Daedophamide (82) is a lead compound from the Indonesian sponge that shows breast cancer inhibition (Table S1). The list then followed with bromotyrosine derivatives, compound $\mathbf{3 7}$ and $\mathbf{3 8}$, which show the same pattern from previously discussed cell lines. Despite the similar value of $\mathrm{IC}_{50}$ shown by $\beta$-carboline derivatives, compounds $\mathbf{9}$ and $\mathbf{1 0}$, the cytotoxicity is unfitted to be compared directly because different breast cancer cell lines, i.e., MCF7 and MDAMB-231, were assayed. The difference between MCF7 and MDA-MB-231 lies in the enrichment of Ki67-antigen on the cell lines. The presence of Ki67 on the MDA-MB-231 remarks the aggressiveness and increase on cell migration of the cell lines compared to MCF7, classified as low-Ki67 cell lines (Holliday and Speirs 2011; Yuan et al. 2016). Nevertheless, the comprehensive comparison of the listed compounds is still limited. For instance, compounds 31-36 only include percent of observed growth against MCF7 cell lines, although they show an attractive feature in terms of selectivity. On the other hand, the compound araplysillin VII (34) with a distinctive guaidino terminus and isoxazole moiety displayed a higher potential on the percent of growth observed against MCF7 than A549 cell lines. This finding indicates that the MCF7 cell line is more prone to the isoxazole moiety than the free ketoxime.

\section{HeLa Cell Line}

HeLa cell line is the first continuous cancer cell line and one of the most commonly used cell lines among many disciplines (Masters 2002). One of the studies representing the intersection between HeLa cell lines and MNPs from Indonesian sponges is the study of Xestospongia testudinaria extract. Through the MTT assay, the partitioned-methanolic extract showed potent activity against the HeLa cell line with $\mathrm{IC}_{50}$ value of $2.273 \mathrm{ppm}$ (Swantara et al. 2019). The obtained inhibition represents the potential of the Indonesian marine sponge as a promising source for cytotoxic MNPs (Table S1). The HeLa cell line inhibition by the isolated compounds is led by a peptide, carteritins $\mathrm{A}(\mathbf{8 6})$, with $\mathrm{IC}_{50}$ of $0.7 \mu \mathrm{M}$. On the other hand, hymenamides $\mathrm{C}(\mathbf{8 8})$ and phakellistatin $13(\mathbf{8 7})$ are listed with a significantly lower activity with $\mathrm{IC}_{50}$ of 15 and $25 \mu \mathrm{M}$, respectively. Besides peptides, the galactoside-triterpenes show a tenfold decrease in activity for both melophluosides A (76) and B (77).

On a broader view, comparison with synthetic derivatives of diaminoindoloylthiazoles (104; HeLa IC $\left.\mathrm{I}_{50} 1 \mu \mathrm{M}\right)$ and thiopyranopyrimidine derivatives $\left(\mathbf{1 0 5} ; \mathrm{HeLa} \mathrm{IC}_{50}\right.$ $0.104 \mu \mathrm{M}$ ) were included as a SAR benchmark on HeLa cytotoxicity (Juneja et al. 2013; Zhao et al. 2020). The two nitrogen atoms and indole group on both compounds are essentials to provide bidentate hydrogen bonding and increase binding affinity, respectively. In addition, the presence of an extended acrylamide group avoids unnecessary binding to non-target proteins which reduced the potential side effects. The avoidance is provided by increasing binding affinity to the Cys797 residue on the epidermal growth factor receptor (EGFR) signaling pathway on HeLa cell line. The combination of these moieties resulted in tenfold increase of cytotoxicity against HeLa (Zhao et al. 2020). However, the isolated compounds from Indonesian marine sponges that are assayed against HeLa does not contain these moieties, except the potent carteritins A (86). 
<smiles>COc1ccc(-c2nc(N)c(C(=O)c3cc4ccccc4[nH]3)s2)cc1</smiles>

104<smiles>CCC/C=C\C(=O)Nc1cc(Nc2nc3c(c(-c4cn(C)c5ccccc45)n2)CS(=O)(=O)CC3)c(OC)cc1N(C)CCN(C)C</smiles>

105

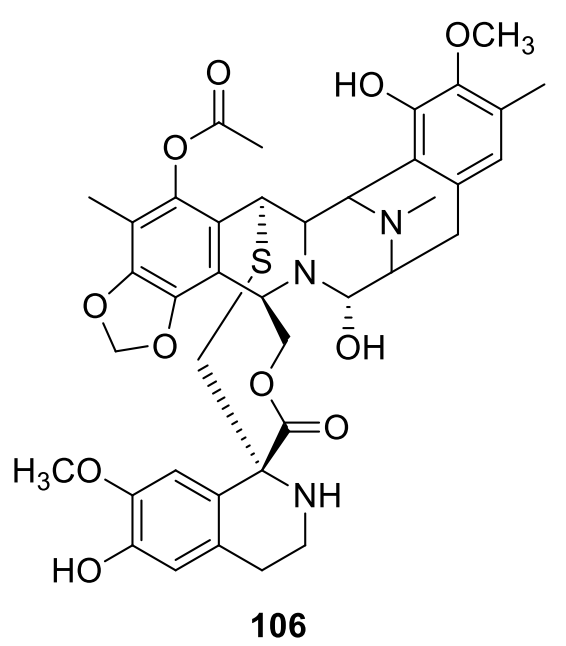

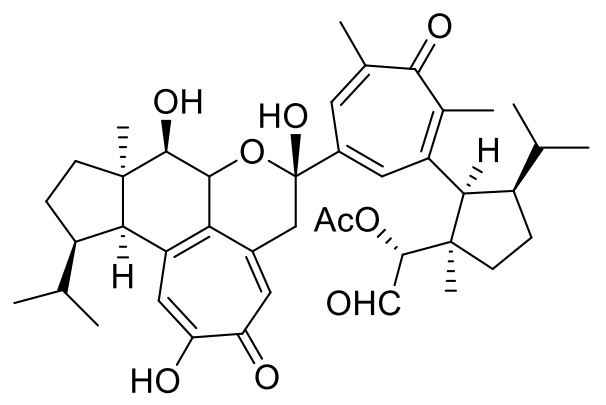

107

\section{A2780 and Related Cell Lines}

The search for another therapeutic agent for ovarian cancer is imminent for its recurring possibility and low survival rate (McClung and Wenham 2016; Erba et al. 2001). The famous A2780 cell line MNP inhibitors are the ecteinascidin-743 (ET-743) (106) (Erba et al. 2001) which is marketed as Yondelis ${ }^{\circledR}$ originated from tunicates and gukulenin A (107), from the marine sponge, Phorbas gukhulensis (Ahn et al. 2019). Despite the different geographical origins, these compounds have shown remarkable cytotoxicity against the A2780 cell line and marked their way of being the candidate for cancer therapeutic options. Another contribution that can be taken from these compounds is the essential functional group or a specific moiety to be compared with Indonesian origin MNPs. Ecteinascidin-743 (ET-743) (106) and gukulenin A (107) stand as the leaders on the list with a more than tenfold increase in cytotoxicity as compared to other Indonesian isolated compounds. On the Indonesian sides of the list, the cytotoxicity is led by peptides represented by microcionamide $\mathrm{C}, \mathrm{D}$, and $\mathrm{A}(\mathbf{8 3}-\mathbf{8 5})$, followed by the bromotyrosine derivatives (31-36).
Despite being found as the less cytotoxic compounds from Indonesian marine sponges, the bromotyrosine derivatives also provide a selectivity feature on the compound tested. A few compounds which show inhibition against normal mouse fibroblast (NIH3T3) is eliminated from the potential category, resulting in purpuramine $\mathrm{M}(\mathbf{3 1})$ with $\mathrm{IC}_{50} 20 \mu \mathrm{M}$ as a promising candidate. In addition to the selective screening of activity, the research also provides an $\mathrm{IC}_{50} 40 \mu \mathrm{M}$ value for A2780-CP5 cell line of 31. This early screening will be beneficial for further development of $\mathbf{3 1}$ as a drug candidate and further SAR study on MNPs for their activity against the A2780 cell line, especially for the cisplatin-resistant cell lines (Table S2).

\section{Colorectal Cancer Cell Lines}

The HT-29 and HCT116 cell lines are well-known in the race to obtain new therapeutic strategies in fighting one of the most commonly diagnosed cancers considering their development of metastases and their low 5-year survival rate (Xu et al. 2020). On MNPs from Indonesian sponges, a few candidates with promising activity on inhibiting HT-29 and HCT116 cell lines are listed in Table S2. The isolated 
compounds consist of peptides, $\beta$-carboline, and bromotyrosine derivatives. Peptides lead the list with an interesting competition between daedophamide (82) and the smaller size, carteritins A (86), phakellistatin 13 (87), and hymenamides $\mathrm{C}(\mathbf{8 8})$. However, both group's $\mathrm{IC}_{50}$ values cannot be compared directly for the different aggressiveness between HT-29 and HCT116 cell lines. The HT-29 cell line is known for its ability to differentiate, compared to the HCT116 cell line, which is more aggressive with nondifferentiating growth (Yeung et al. 2010; Olejniczak et al. 2018). The less aggressive HT-29 cell line is more prone to large peptides (Table S2), daedophamide (82) with an $\mathrm{IC}_{50}$ value of $0.6 \mu \mathrm{M}$. This activity is still considered promising as compared to its positive control doxorubicin $\left(\mathrm{IC}_{50}\right.$ $0.3 \mu \mathrm{M})$, despite the twofold increase in activity. Besides the peptides, the HT-29 cell line is also shown to be sensitive to the bromotyrosine derivatives, aplyzanzine B (38) and anomoian B (37), which contrast with its low cytotoxicity against A549 cell lines. For its possibilities in selective inhibition of colorectal cancer cell line, it is interesting to further examine these bromotyrosine derivatives on the HCT116 cell line. The same prediction is also applied to reverse the scenario for peptides, carteritins A (86) and hymenamides C (87), on their inhibition against HT-29 cell lines. This predictive examination will be beneficial to obtain the selectivity and mechanism of action for both compounds and the cancer cell line target.

The emergence of $\beta$-carboline derivatives on the list also put another interesting attention. The compounds ingenine C (9) and ingenine D (10) showed moderate activity against the HCT116 cell line with $\mathrm{IC}_{50}$ of 2.90 and $3.35 \mu \mathrm{M}$, respectively. A different study suggests that manzamine A (1), another $\beta$-carboline alkaloid, also shows similar cytotoxicity against the HCT116 cell line with $\mathrm{IC}_{50}$ of $4.5 \mu \mathrm{M}$ and $10 \mu \mathrm{M}$ against HT-29 cell line (Lin et al. 2018). These results suggest that the HCT116 cell line is more prone to $\beta$-carboline moiety than the HT-29 cell line. Another SAR study also braces the ideas on the significance of appropriate substituent on $\mathrm{C} 1$ to enhance the cytotoxicity of $\beta$-carboline compounds on various target cell lines (Dai et al. 2018; Aaghaz et al. 2021).

\section{L5178Y Cell Line}

The recently isolated peptides lead the list of cytotoxic compounds against mouse lymphoma cell lines (Table S3). A feature worth mentioning is the efficacy as cytotoxic agents of cyclic compounds compared to acyclic compounds. This feature marked by the leading the acyclic jasplakinolide (89) and (+)-jasplakinolide V (92) followed with the cinachylenic acid A-D (72-75) with the possession of a straight chain. However, $(+)$-jasplakinolide $Z_{5}(\mathbf{9 1})$ displayed a similar cytotoxicity against the L5178Y cell line despite the acyclic form. This finding reduces the significance of the cyclic form in comparison with the carboxylic acid moiety presented by $(+)$-jasplakinolide $\mathrm{Z}_{6}(\mathbf{9 0})$, which was supposed to lower the cytotoxicity. This speculation comes in accordance with a previous study on jasplakinolides family with similar cytotoxicity observed for both acyclic and cyclic members. Further assessment on the jasplakinolides has brought to attention the acyclic compound for a specific activity as stabilizers of filamentous-actin (F-actin) on the cytoskeleton of HCT-116 cells. The F-actin stabilization believed to cause the disruption of the actin cytoskeleton on the colon cancer cell tested on the acyclic compound. However, the acyclic members that contains carboxylic acid and hydroxide terminus, similar to $\mathbf{9 0}$, were not active (Watts et al. 2011).

\section{Inhibition on Cellular Processes}

The attention to the cytotoxicity of MNPs, mainly Indonesian marine sponges, is also shown to inhibit various noncell targets. The non-cell target assay is mainly conducted by inhibiting cell process-related targets such as USP7, VHR, and RANKL-induced osteoclastogenesis. The USP7 inhibition (Table S3) is led by xestoquinone (71), dimeric- $(\mathbf{3}, \mathbf{6 9}$, and 70), and trimeric- ( 68 and 2 ) form of xestoquinone and followed by the furanosesterterpenes (78-81). It is previously discussed that the inhibition of USP7 is closely related to the unsubtituted position of the quinonoid moiety. This supposed relationship is counteracted with a slightly similar unsubstituted position on the $\alpha$-carbon atom presented by furan moiety on compound (78-81) for their marginal $\mathrm{IC}_{50}$ value compared to petroquinone A $(\mathbf{6 8})$. This finding indicates that the USP7 is specifically sensitive to an unsubstituted position of $\alpha$-carbon atom on quinonoid. Another interesting comparison is shown by the emergence of ent-13-norisocopalen-15-al-18-oic acid (53), which contains aldehyde terminus. Compound $\mathbf{5 3}$ shows a slightly small inhibition against USP7 with an $\mathrm{IC}_{50} 8.2 \mu \mathrm{M}$. Its low cytotoxicity might be related to the presence of the fused cyclohexane towards the aldehyde moiety. This finding is supported by a recent review that discusses formaldehyde's reactivity towards cysteine, producing disruption on disulfide linkage and possibly inhibiting USP7 as a member of cysteine protease (Kamps et al. 2019).

The non-cell target inhibition also covered the RANKLinduced osteoclastogenesis. This inhibition of RANKL production is rationalized by the possibility of cancer cells that developed into bone metastasis. Despite the lack of cytotoxicity against its cancer cell line, the inhibitor of RANKL-induced osteoclastogenesis can decrease the bone destruction rate (Bi et al. 2017). This inhibitory activity is shown by cylonamides A-C (43-45) and ceylonins A, D, and $\mathrm{F}(\mathbf{5 0 - 5 2})$. One of the most promising candidates was 
ceylonamides A (43) with an $\mathrm{IC}_{50}$ value of $13 \mu \mathrm{M}$. This finding indicates the sensitivity of RANKL-induced osteoclastogenesis towards meroterpenes amide with ethylbenzene attachment to the nitrogen atom.

\section{Perspectives and Future Directions}

The exposure of Indonesian marine sponges and their secondary metabolites unveiled their potential as cytotoxic agents. One of the covered possibilities is that one compound might bear cytotoxicity for a different cytotoxic target. The highlighted example for this distinctive feature is well-presented by the A549-inactive ingenins C (9) and D (10), whereas it is found to moderately inhibit MCF7 and HCT116 cell lines (Ibrahim and Mohamed 2016). The same pattern also emerges from the isolated peptides from the Indonesian marine sponge, hymenamides $\mathrm{C}(\mathbf{8 8})$, which is found to show potent cytotoxicity against the HCT116 cell line and weakly inhibit HeLa cell line (Afifi et al. 2016). The comparison between studies on the same cytotoxic target also shows a couple of conjectures. These can be seen from the significance of carboxylic acid moiety that lowered the cytotoxicity of a compound against the L5178Y cell line and the presence of unsubstituted $\alpha$-carbon atom on terpene quinone to provide inhibition against USP7. To summarize the exposition of the isolated cytotoxic compound from the Indonesian marine sponge, peptides emerge as the leader on six out of nine target-oriented SAR studies. This finding suggests that naturally occurring peptides will be a promising compound to be assessed for their cytotoxicities.

The presented comparison of recent studies for Indonesian MNPs from sponge origin has highlighted the attempt to overcome limitations on the early SAR intervention, including the limited number of isolated compounds (Dyshlovoy and Honecker 2019; Ren et al. 2021). The limited amount then gives the limited number of cytotoxicity assays to be performed and the inability to unify the presented cytotoxic value. The different cytotoxic values on the same cytotoxicity target cannot be compared directly, thus limiting the reliability of the comparison itself (Guha 2013). The number of the performed cytotoxic assay on various target cell lines also gives limited views of a compound activity. One of the biggest challenges associated with bioprospecting marine natural products is the low yield of extraction for their pharmacological application, which can compromise pre-clinical and clinical trials and thus the development of a new drug. Several strategies were developed to overcome these limitations, such as genetic engineering, aquaculture/cultivation, chemical modification, semi-synthesis, and synthesis. Chemical synthesis of spongederived compounds or their simpler derivatives offers the most reliable option for sustainable, long-term drug supply if the said compounds can be produced cost-effectively. Emerging technologies such as metagenomics and high-throughput microbial cultivation approaches offer exciting potential for accessing those compounds which are produced by microbial communities in sponges in order to provide essential scaffolds for the synthesis and molecular modeling of new anticancer drugs.

\section{Conclusions}

Cytotoxic natural products from Indonesian marine sponges modulate cancer cell mechanisms in vitro and in vivo in breast, ovarian and colorectal carcinoma cell types, inter alia. These compounds exhibited high specificity and great affinity to interact with distinct biological targets linked to specific intracellular signaling pathways, including mitochondrial dysfunction, autophagy, endoplasmic reticulum stress induction, apoptosis, inflammation, and cell migration. This review comprises a preliminary attempt to fill the gap between chemoinformatics-MNPs and bioinformatics-cytotoxicity study. This combination of approaches on chemoinformatics and bioinformatics will decrease the number of resources to perform cytotoxicity assay for its early intervention to narrow down the options of possible activities on a given isolated compound. This approach also increases the possibilities to obtain an improved accuracy on cytotoxicity targets. Other disciplines involved in this SAR intervention are in silico study, synthetic organic chemistry, and study on the mechanism of action. They provide a feedback loop to guide the discovery of cytotoxic compounds in future MNPs investigations. Besides highlighting towards the rich and complex biodiversity of marine natural products from Indonesian sponges, this review also encouraged SAR utilization on MNPs research and recognized the considered pointless efforts on an inactive compound as a precious addition to future research.

\section{Conflict of Interest}

The authors declare no conflict of interest.

Acknowledgements We gratefully thank Dr. Rogelio Pereda-Miranda, Editor in Chief of Revista Brasileira de Farmacognosia, for the insightful contribution and expert advice to this article during the editorial process.

Author Contributions Material preparation and conceptualization of idea and analysis were performed by JAP, MYP and AB. Literature data collection were contributed by JAP, SPA, TM and SIR. The first draft was written by JAP an all authors commented. All authors have read the final manuscript and approved the submission. 
Funding Financial support was provided from the Indonesian Institute of Sciences (Lembaga Ilmu Pengetahuan Indonesia) through the DIPA 2021 Research Fund B-10405/IPH/HK.01.03/XI/2020.

\section{References}

Aaghaz S, Sharma K, Jain R, Kamal A (2021) $\beta$-Carbolines as potential anticancer agents. Eur J Med Chem 216:113321. https://doi.org/ 10.1016/j.ejmech.2021.113321

Abdel-Rahman SA, El-Damasy AK, Hassan GS, Wafa EI, Geary SM, Maarouf AR, Salem AK (2020) Cyclohepta[b]thiophenes as potential antiproliferative agents: design, synthesis, in vitro, and in vivo anticancer evaluation. ACS Pharmacol Transl Sci 3:965-977. https://doi.org/10.1021/acsptsci.0c00096

Abdjul DB, Yamazaki H, Kanno S, Wewengkang DS, Rotinsulu H, Sumilat DA, Ukai K, Kapojos MM, Namikoshi M (2017) Furanoterpenes, new types of protein tyrosine phosphatase 1B inhibitors, from two Indonesian marine sponges, Ircinia and Spongia spp. Bioorg Med Chem Lett 27:1159-1161. https://doi. org/10.1016/j.bmcl.2017.01.071

Afifi AH, El-Desoky AH, Kato H, Mangindaan REP, De Voogd NJ, Ammar NM, Hifnawy MS, Tsukamoto S (2016) Carteritins A and B, cyclic heptapeptides from the marine sponge Stylissa carteri. Tetrahedron Lett 57:1285-1288. https://doi.org/10.1016/j. tetlet.2016.02.031

Afifi AH, Kagiyama I, El-Desoky AH, Kato H, Mangindaan REP, de Voogd NJ, Ammar NM, Hifnawy MS, Tsukamoto S (2017) Sulawesins A-C, furanosesterterpene tetronic acids that inhibit USP7, from a Psammocinia sp. marine sponge. J Nat Prod 80:2045-2050. https://doi.org/10.1021/acs.jnatprod.7b00184

Ahn JH, Woo JH, Rho JR, Choi JH (2019) Anticancer activity of gukulenin A isolated from the marine sponge Phorbas gukhulensis in vitro and in vivo. Mar Drugs 17:126. https://doi.org/10.3390/ md17020126

Ahmad I, Fakhri S, Khan H, Jeandet P, Aschner M, Yu Z (2020) Targeting cell cycle by $\beta$-carboline alkaloids in vitro: novel therapeutic prospects for the treatment of cancer. Chem Biol Interact 330:109229. https://doi.org/10.1016/j.cbi.2020.109229

Althagbi HI, Alarif WM, Al-Footy KO, Abdel-Lateff A (2020) Marinederived macrocyclic alkaloids (MDMAs): chemical and biological diversity. Mar Drugs 18:368. https://doi.org/10.3390/md180 70368

Arai M, Kamiya K, Shin D, Matsumoto H, Hisa T, Setiawan A, Kotoku N, Kobayashi M (2016) N-methylniphatyne A, a new 3-alkylpyridine alkaloid as an inhibitor of the cancer cells adapted to nutrient starvation, from an Indonesian marine sponge of Xestospongia sp. Chem Pharm Bull 64:766-771. https://doi.org/10.1248/ cpb.c16-00118

Arai M, Shin D, Kamiya K, Ishida R, Setiawan A, Kotoku N, Kobayashi M (2017) Marine spongean polybrominated diphenyl ethers, selective growth inhibitors against the cancer cells adapted to glucose starvation, inhibits mitochondrial complex II. J Nat Med 71:44-49. https://doi.org/10.1007/s11418-016-1025-x

Aron ZD, Pietraszkiewicz H, Overman LE, Valeriote F, Cuevas C (2004) Synthesis and anticancer activity of side chain analogs of the crambescidin alkaloids. Bioorg Med Chem Lett 14:34453449. https://doi.org/10.1016/j.bmcl.2004.04.071

Arshad N, Zitterl-Eglseer K, Hasnain S, Hess M (2008) Effect of Peganum harmala or its $\beta$-carboline alkaloids on certain antibiotic resistant strains of bacteria and protozoa from poultry. Phytother Res 22:1533-1538. https://doi.org/10.1002/ptr.2528

Ashok P, Lathiya H, Murugesan S (2015) Manzamine alkaloids as antileishmanial agents: a review. Eur J Med Chem 97:928-936. https://doi.org/10.1016/j.ejmech.2014.07.006
Ayipo YO, Mordi MN, Mustapha M, Damodaran T (2020) Neuropharmacological potentials of $\beta$-carboline alkaloids for neuropsychiatric disorders. Eur J Pharmacol 893:173837. https://doi.org/10. 1016/j.ejphar.2020.173837

Banerjee R, Kumar HK, Banerjee M (2012) Medicinal significance of furan derivatives: a review. Int J Rev Life Sci 5:48-57

Bao Y, Xu Q, Wang L, Wei Y, Hu B, Wang J, Liu D, Zhao L, Jing $\mathrm{Y}$ (2021) Studying histone deacetylase inhibition and apoptosis induction of Psammaplin A monomers with modified thiol group. ACS Med Chem Lett 12:39-47. https://doi.org/10.1021/acsme dchemlett.0c00369

Barbero H, Díez-Poza C, Barbero A (2017) The oxepane motif in marine drugs. Mar Drugs 15:361. https://doi.org/10.3390/md151 10361

Bashari MH, Arsydinilhuda FZ, Ilhamsyah RS, Nugrahani AD, Nurdin RA, Kartikasari A, Huda F, Abdurahman M, Putri T, Qomarilla N, Atmaja H, Sudji IR, Subhan B, Usman HA, Pamela Y, Ariyanto EF, Meiyanto E (2021) The ethanol extract of marine sponge Aaptos suberitoides suppress cell viability, cell proliferation and cell migration in HER2-positive breast cancer cell line. Asian Pac J Cancer Prev 22:25-32. https://doi.org/10.31557/ APJCP.2021.22.S1.25

Baud MGJ, Leiser T, Haus P, Samlal S, Wong AC, Wood RJ, Petrucci V, Gunaratnam M, Hughes SM, Buluwela L, Turlais F, Neidle S, Meyer-Almes FJ, White AJP, Fuchter MJ (2012) Defining the mechanism of action and enzymatic selectivity of psammaplin A against its epigenetic targets. J Med Chem 55:1731-1750. https:// doi.org/10.1021/jm2016182

Bi H, Chen X, Gao S, Yu X, Xiao J, Zhang B, Liu X, Dai M (2017) Key triggers of osteoclast-related diseases and available strategies for targeted therapies: a review. Front Med 4:1-10. https://doi.org/ 10.3389/fmed.2017.00234

Bidleman TF, Andersson A, Jantunen LM, Kucklick JR, Kylin H, Letcher RJ, Tysklind M, Wong F (2019) A review of halogenated natural products in Arctic, Subarctic and Nordic ecosystems. Emerg Contam 5:89-115. https://doi.org/10.1016/j.emcon.2019.02.007

Blunt JW, Copp BR, Keyzers RA, Munro MHG, Prinsep MR (2015) Marine natural products. Nat Prod Rep 32:116-211. https://doi. org/10.1039/c4np00144c

Brown AC, Fraser TR (1868) On the connection between chemical constitution and physiological action; with special reference to the physiological action of the salts of the ammonium bases derived from Strychnia, Brucia, Thebaia, Codeia, Morphia, and Nicotia. J Anat Physiol 2:224-242

Cao R, Peng W, Wang Z, Xu A (2007) $\beta$-carboline alkaloids: biochemical and pharmacological functions. Curr Med Chem 14:479-500. https://doi.org/10.2174/092986707779940998

Caro-Diaz EJE, Valeriote FA, Gerwick WH (2019) Highly convergent total synthesis and assignment of absolute configuration of majusculamide $\mathrm{D}$, a potent and selective cytotoxic metabolite from Moorea sp. Org Lett 21:793-796. https://doi.org/10.1021/ acs.orglett. $8 \mathrm{~b} 04050$

Chatterjee J, Gilon C, Hoffman A, Kessler H (2008) N-methylation of peptides: a new perspective in medicinal chemistry. Acc Chem Res 41:1331-1342. https://doi.org/10.1021/ar8000603

Choudhuri S, Chanderbhan R, Mattia A (2007) Carcinogenesis: mechanisms and models. In: Gupta RC (ed) Veterinary Toxicology: Basic and Clinical Principles, 1st edn. Elsevier, New York, pp 343-359

Cowan J, Shadab M, Nadkarni DH, Kailash KC, Velu SE, Yusuf N (2019) A novel marine natural product derived pyrroloiminoquinone with potent activity against skin cancer cells. Mar Drugs 17:443. https://doi.org/10.3390/md17080443

Dai J, Parrish SM, Yoshida WY, Yip MLR, Turkson J, Kelly M, Williams P (2016) Bromotyrosine-derived metabolites from an Indonesian marine sponge in the family Aplysinellidae (Order 
Verongiida). Bioorg Med Chem Lett 26:499-504. https://doi.org/ 10.1016/j.bmcl.2015.11.086

Dai J, Dan W, Schneider U, Wang J (2018) $\beta$-Carboline alkaloid monomers and dimers: occurrence, structural diversity, and biological activities. Eur J Med Chem 157:622-656. https://doi.org/10. 1016/j.ejmech.2018.08.027

Dyshlovoy SA, Honecker F (2019) Marine compounds and cancer: the first two decades of XXI century. Mar Drugs 18:20. https://doi. org/10.3390/md18010020

Ebada SS, de Voogd N, Kalscheuer R, Müller WEG, Chaidir PP (2017) Cytotoxic drimane meroterpenoids from the Indonesian marine sponge Dactylospongia elegans. Phytochem Lett 22:154-158. https://doi.org/10.1016/j.phytol.2017.09.026

Ebada SS, Müller WEG, Lin W, Proksch P (2019) New acyclic cytotoxic jasplakinolide derivative from the marine sponge Jaspis splendens. Mar Drugs 17:100. https://doi.org/10.3390/md170 20100

Ebada SS, Proksch P (2012) The chemistry of marine sponges. In: Fattorusso E, Gerwick W, Taglialatela-Scafati O (eds) Handbook of Marine Natural Products. Springer, Dordrecht, pp 191-293

El-Desoky AH, Kato H, Angkouw ED, Mangindaan REP, de Voogd NJ, Tsukamoto S (2016) Ceylonamides A-F, nitrogenous spongian diterpenes that inhibit RANKL-induced osteoclastogenesis, from the marine sponge Spongia ceylonensis. J Nat Prod 79:1922-1928. https://doi.org/10.1021/acs.jnatprod.6b00158

El-Desoky AH, Kato H, Kagiyama I, Hitora Y, Losung F, Mangindaan REP, de Voogd NJ, Tsukamoto S (2017a) Ceylonins A-F, spongian diterpene derivatives that inhibit RANKL-induced formation of multinuclear osteoclasts, from the marine sponge Spongia ceylonensis. J Nat Prod 80:90-95. https://doi.org/10.1021/acs. jnatprod.6b00725

El-Desoky AH, Kato H, Tsukamoto S (2017b) Ceylonins G-I: spongian diterpenes from the marine sponge Spongia ceylonensis. J Nat Med 71:765-769. https://doi.org/10.1007/s11418-017-1087-4

Erba E, Bergamaschi D, Bassano L, Damia G, Ronzoni S, Faircloth GT, D'Incalci M (2001) Ecteinascidin-743 (ET-743), a natural marine compound, with a unique mechanism of action. Eur $\mathbf{J}$ Cancer 37:97-105. https://doi.org/10.1016/S0959-8049(00) 00357-9

Esposito G, Bourguet-Kondracki ML, Mai LH, Longeon A, Teta R, Meijer L, Van Soest R, Mangoni A, Costantino V (2016) Chloromethylhalicyclamine $\mathrm{B}$, a marine-derived protein kinase CK1ס/ inhibitor. J Nat Prod 79:2953-2960. https://doi.org/10.1021/acs. jnatprod.6b00939

García-Reyes B, Witt L, Jansen B, Karasu E, Gehring T, Leban J, Henne-Bruns D, Pichlo C, Brunstein E, Baumann U, Wesseler F, Rathmer B, Schade D, Peifer C, Knippschild U (2018) Discovery of inhibitor of Wnt production 2 (IWP-2) and related compounds as selective ATP-competitive inhibitors of casein kinase 1 (CK1) ठ/є. J Med Chem 61:4087-4102. https://doi.org/10.1021/acs. jmedchem.8b00095

Geahchan S, Ehrlich H, Rahman MA (2021) The anti-viral applications of marine resources for COVID-19 treatment: an overview. Mar Drugs 19:409. https://doi.org/10.3390/md19080409

Gershenzon J, Dudareva N (2007) The function of terpene natural products in the natural world. Nat Chem Biol 3:408-414. https://doi. org/10.1038/nchembio.2007.5

Gomes N, Buttachon S, Kijjoa A (2015) Meroterpenoids from marine microorganisms: potential scaffolds for new chemotherapy leads. In: Kim SK (ed) Handbook of Anticancer Drugs from Marine Origin. Springer, Cham, pp 323-366

Gonzalez MM, Cabrerizo FM, Baiker A, Erra-Balsells R, Ostermana A, Nitschkoa H, Vizoso-Pintoa MG (2018) $\beta$-Carboline derivatives as novel antivirals for herpes simplex virus. Int J Antimicrob Agents 52:459-468. https://doi.org/10.1016/j.ijantimicag. 2018.06.019
Grieco I, Bissaro M, Tiz DB, Perez DI, Perez C, Martinez A, Redenti S, Mariotto E, Bortolozzi R, Viola G, Cozza G, Spalluto G, Moro S, Federico S (2021) Developing novel classes of protein kinase CK1 $\delta$ inhibitors by fusing $[1,2,4]$ triazole with different bicyclic heteroaromatic systems. Eur J Med Chem 216:113331. https:// doi.org/10.1016/j.ejmech.2021.113331

Gross H, König GM (2006) Terpenoids from marine organisms: unique structures and their pharmacological potential. Phytochem Rev 5:115-141. https://doi.org/10.1007/s11101-005-5464-3

Guha R (2013) On exploring structure-activity relationships. Methods Mol Biol 993:81-94. https://doi.org/10.1007/ 978-1-62703-342-8_6

Hamann M, Alonso D, Martín-Aparicio E, Fuertes A, Pérez-Puerto MJ, Castro A, Morales S, Navarro ML, Del Monte-Millán M, Medina M, Pennaka H, Balaiah A, Peng J, Cook J, Wahyuono S, Martínez A (2007) Glycogen synthase kinase-3 (GSK-3) inhibitory activity and structure-activity relationship (SAR) studies of the manzamine alkaloids. Potential for Alzheimer's disease. J Nat Prod 70:1397-1405. https://doi.org/10.1021/ np060092r

Hanif N, Murni A, Tanaka C, Tanaka J (2019) Marine natural products from Indonesian waters. Mar Drugs 17:364. https://doi.org/10. 3390/md17060364

Hitora Y, Sejiyama A, Honda K, Ise Y, Losung F, Mangindaan REP, Tsukamoto S (2021) Fluorescent image-based high-content screening of extracts of natural resources for cell cycle inhibitors and identification of a new sesquiterpene quinone from the sponge Dactylospongia Metachromia. Bioorg Med Chem 31:115968. https://doi.org/10.1016/j.bmc.2020.115968

Holliday DL, Speirs V (2011) Choosing the right cell line for breast cancer research. Breast Cancer Res 13:215. https://doi.org/10. 1186/bcr2889

Hu X, Xiao Y, Sun J, Ji B, Luo S, Wu B, Zheng C, Wang P, Xu F, Cheng K, Hua H, Li D (2021) New possible silver lining for pancreatic cancer therapy: hydrogen sulfide and its donors. Acta Pharm Sin B 11:1148-1157. https://doi.org/10.1016/j.apsb.2020. 10.019

Ibrahim SRM, Mohamed GA (2016) Ingenines C and D, new cytotoxic pyrimidine- $\beta$-carboline alkaloids from the Indonesian sponge Acanthostrongylophora ingens. Phytochem Lett 18:168-171. https://doi.org/10.1016/j.phytol.2016.10.014

Izzati F, Warsito MF, Bayu A, Prasetyoputri A, Atikana A, Sukmarini L, Rahmawati SI, Putra MY (2021) Chemical diversity and biological activity of secondary metabolites isolated from Indonesian marine invertebrates. Molecules 26:1898. https://doi.org/10. 3390/molecules26071898

Jomori T, Setiawan A, Sasaoka M, Arai M (2019) Cytotoxicity of new diterpene alkaloids, ceylonamides G-I, isolated from Indonesian marine sponge of Spongia sp. Nat Prod Commun 14:1-7. https:// doi.org/10.1177/1934578X19857294

Juneja M, Vanam U, Paranthaman S, Bharathan A, Keerthi VS, Reena JK, Rajaram R, Rajasekharan KN, Karunagaran D (2013) 4-Amino-2-arylamino-5-indoloyl/cinnamoythiazoles, analogs of topsentin-class of marine alkaloids, induce apoptosis in HeLa cells. Eur J Med Chem 63:474-483. https://doi.org/10.1016/j. ejmech.2013.02.032

Kamps JJAG, Hopkinson RJ, Schofield CJ, Claridge TDW (2019) How formaldehyde reacts with amino acids. Commun Chem 2:126. https://doi.org/10.1038/s42004-019-0224-2

Karan D, Dubey S, Pirisi L, Nagel A, Pina I, Choo YM, Hamann MT (2020) The marine natural product manzamine A inhibits cervical cancer by targeting the SIX1 protein. J Nat Prod 83:286-295. https://doi.org/10.1021/acs.jnatprod.9b00577

Kasmiati K, Yoshioka Y, Okamoto T, Ojika M (2018) New crambescidin-type alkaloids from the Indonesian marine sponge Clathria bulbotoxa. Mar Drugs 16:84. https://doi.org/10.3390/md16030084 
Kato H, El-Desoky AH, Takeishi Y, Nehira T, Angkouw ED, Mangindaan REP, de Voogd NJ, Tsukamoto S (2019) Tetradehydrohalicyclamine B, a new proteasome inhibitor from the marine sponge Acanthostrongylophora ingens. Bioorg Med Chem Lett 29:8-10. https://doi.org/10.1016/j.bmcl.2018.11.028

Kiełbasiński P, Kwiatkowska M, Cierpiał T, Rachwalski M, Leśniak S (2019) The sulfinyl group: Its importance for asymmetric synthesis and biological activity. Phosphorus Sulfur Silicon Relat Elem 194:649-653. https://doi.org/10.1080/10426507.2019.1602622

Kim BR, Ha J, Kang E, Cho S (2020) Regulation of signal transducer and activator of transcription 3 activation by dual-specificity phosphatase 3. BMB Rep 53:335-340. https://doi.org/10.5483/ BMBRep.2020.53.6.054

Kim CK, Riswanto R, Won TH, Kim H, Elya B, Sim CJ, Oh DC, Oh KB, Shin J (2017) Manzamine alkaloids from an Acanthostrongylophora sp. sponge. J Nat Prod 80:1575-1583. https://doi.org/ 10.1021/acs.jnatprod.7b00121

König GM, Kehraus S, Seibert SF, Abdel-Lateff A, Müller D (2006) Natural products from marine organisms and their associated microbes. ChemBioChem 7:229-238. https://doi.org/10.1002/ cbic. 200500087

Kotoku N, Ishida R, Matsumoto H, Arai M, Toda K, Setiawan A, Muraoka O, Kobayashi M (2017) Biakamides A-D, unique polyketides from a marine sponge, act as selective growth inhibitors of tumor cells adapted to nutrient starvation. J Org Chem 82:1705-1718. https://doi.org/10.1021/acs.joc.6b02948

Kumar MS, Patravale VB (2020) Marine-derived potential antiinflammatory agents. In: Kim SK (ed) Encyclopedia of Marine Biotechnology. Wiley, pp 2585-2605. https://doi.org/10.1002/ 9781119143802.ch116

Lee Y, Phat C, Hong SC (2017) Structural diversity of marine cyclic peptides and their molecular mechanisms for anticancer, antibacterial, antifungal, and other clinical applications. Peptides 95:94-105. https://doi.org/10.1016/j.peptides.2017.06.002

Li P, Liu HM (2020) Recent advances in the development of ubiquitin-specific-processing protease 7 (USP7) inhibitors. Eur J Med Chem 191:112107. https://doi.org/10.1016/j.ejmech.2020. 112107

Lin LC, Kuo TT, Chang HY, Liu WS, Hsia SM, Huang TC (2018) Manzamine A exerts anticancer activity against human colorectal cancer cells. Mar Drugs 16:1-15. https://doi.org/10.3390/md160 80252

Lin S, McCauley EP, Lorig-Roach N, Tenney K, Naphen CN, Yang AM, Johnson TA, Hernadez T, Rattan R, Valeriote FA, Crews P (2017) Another look at pyrroloiminoquinone alkaloids-perspectives on their therapeutic potential from known structures and semisynthetic analogues. Mar Drugs 15:98. https://doi.org/10. 3390/md15040098

Long A, Zhao H, Huang X (2012) Structural basis for the interaction between casein kinase 1 delta and a potent and selective inhibitor. J Med Chem 55:956-960. https://doi.org/10.1021/jm201387s

Lorig-Roach N, Hamkins-Indik F, Johnson TA, Tenney K, Valeriote FA, Crews $\mathrm{P}$ (2018) The potential of achiral sponge-derived and synthetic bromoindoles as selective cytotoxins against PANC-1 tumor cells. Tetrahedron 74:217-223. https://doi.org/10.1016/j. tet.2017.11.029

Maarisit W, Abdjul DB, Yamazaki H, Kato H, Rotinsulu H, Wewengkang DS, Sumilat DA, Kapojos MM, Ukai K, Namikoshi M (2017) Anti-mycobacterial alkaloids, cyclic 3-alkyl pyridinium dimers, from the Indonesian marine sponge Haliclona sp. Bioorg Med Chem Lett 27:3503-3506. https://doi.org/10.1016/j.bmcl. 2017.05.067

Masters JR (2002) HeLa cells 50 years on: the good, the bad and the ugly. Nat Rev Cancer 2:315-319. https://doi.org/10.1038/nrc775

Matsunaga S, Fusetani N, Konosu S (1984) Bioactive marine metabolites VI structure elucidation of discodermin a, an antimicrobial peptide from the marine sponge Discodermia kiiensis. Tetrahedron Lett 25:5165-5168. https://doi.org/10.1016/S00404039(01)81553-7

McClung EC, Wenham RM (2016) Profile of bevacizumab in the treatment of platinum-resistant ovarian cancer: current perspectives. Int J Womens Health 8:59-75. https://doi.org/10.2147/IJWH. S78101

McKinney JD, Richard A, Waller C, Newman MC, Gerberick F (2000) The practice of structure activity relationships (SAR) in toxicology. Toxicol Sci 56:8-17. https://doi.org/10.1093/ toxsci/ $/ 56.1 .8$

Mehbub MF, Lei J, Franco C, Zhang W (2014) Marine sponge derived natural products between 2001 and 2010: trends and opportunities for discovery of bioactives. Mar Drugs 12:4539-4577. https://doi.org/10.3390/md12084539

Mfuh AM, Larionov OV (2015) Heterocyclic $N$-oxides - an emerging class of therapeutic agents. Curr Med Chem 22:2819-2857. https://doi.org/10.2174/0929867322666150619104007

Mokhlesi A, Hartmann R, Kurtán T, Weber H, Lin W, Chaidir C, Müller WEG, Daletos G, Proksch P (2017a) New 2-methoxy acetylenic acids and pyrazole alkaloids from the marine sponge Cinachyrella sp. Mar Drugs 15:1-45. https://doi.org/10.3390/ md15110356

Mokhlesi A, Stuhldreier F, Wex KW, Berscheid A, Hartmann R, Rehberg N, Sureechatchaiyan P, Chaidir C, Kassack MU, Kalscheuer R, Brötz-Oesterhelt H, Wesselborg S, Stork B, Daletos G, Proksch P (2017b) Cyclic cystine-bridged peptides from the marine sponge Clathria basilana induce apoptosis in tumor cells and depolarize the bacterial cytoplasmic membrane. J Nat Prod 80:2941-2952. https://doi.org/10.1021/acs.jnatprod. $7 \mathrm{~b} 00477$

Nasr T, Bondock S, Youns M (2014) Anticancer activity of new coumarin substituted hydrazide-hydrazone derivatives. Eur J Med Chem 76:539-548. https://doi.org/10.1016/j.ejmech.2014.02. 026

Northfield SE, Wang CK, Schroeder CI, Durek T, Kan MW, Swedberg JE, Craik DJ (2014) Disulfide-rich macrocyclic peptides as templates in drug design. Eur J Med Chem 77:248-257. https://doi. org/10.1016/j.ejmech.2014.03.011

Olejniczak A, Szaryńska M, Kmieć Z (2018) In vitro characterization of spheres derived from colorectal cancer cell lines. Int J Oncol 52:599-612. https://doi.org/10.3892/ijo.2017.4206

Pavic K, Duan G, Köhn M (2015) VHR/DUSP3 phosphatase: structure, function and regulation. FEBS J 282:1871-1890. https://doi.org/ 10.1111/febs. 13263

Peng J, Hu JF, Kazi AB, Li Z, Avery M, Peraud O, Hill RT, Franzblau SG, Zhang F, Schinazi RF, Wirtz SS, Tharnish P, Kelly M, Wahyuono S, Hamann MT (2003) Manadomanzamines A and B: a novel alkaloid ring system with potent activity against mycobacteria and HIV-1. J Am Chem Soc 125:13382-13386. https://doi.org/10.1021/ja030087z

Peng J, Kudrimoti S, Prasanna S, Odde S, Doerksen RJ, Pennaka HK, Choo YM, Rao KV, Tekwani BL, Madgula V, Khan SI, Wang B, Mayer AMS, Jacob MR, Tu LC, Gertsch J, Hamann MT (2010) Structure-activity relationship and mechanism of action studies of manzamine analogues for the control of neuroinflammation and cerebral infections. J Med Chem 53:61-76. https://doi.org/ 10.1021/jm900672t

Rao KV, Donia MS, Peng J, García-Palomero E, Alonso D, Martinez A, Medina M, Franzblau SG, Tekwani BL, Khan SI, Wahyuono S, Willett KL, Hamann MT (2006) Manzamine B and E and Ircinal A related alkaloids from an Indonesian Acanthostrongylophora sponge and their activity against infectious, tropical parasitic, and Alzheimer's diseases. J Nat Prod 69:1034-1040. https://doi.org/10.1021/np0601399 
Ren X, Xie X, Chen B, Liu L, Jiang C, Qian Q (2021) Marine natural products: a potential source of anti-hepatocellular carcinoma drugs. J Med Chem 4:7879-7899. https://doi.org/10.1021/acs. jmedchem.0c02026

Rodrigues RP, de Silva CHTP (2017) Discovery of potential neurodegenerative inhibitors in Alzheimer's disease by casein kinase 1 structure-based virtual screening. Med Chem Res 26:3274-3285. https://doi.org/10.1007/s00044-017-2020-9

Roel M, Rubiolo JA, Guerra-Varela J, Silva SBL, Thomas OP, Cabezas-Sainz P, Sánchez L, López R, Botana LM (2016) Marine guanidine alkaloids crambescidins inhibit tumor growth and activate intrinsic apoptotic signaling inducing tumor regression in a colorectal carcinoma zebrafish xenograft model. Oncotarget 7:83071-83087. https://doi.org/10.18632/oncotarget. 13068

Ruocco N, Costantini S, Palumbo F, Costantini M (2017) Marine sponges and bacteria as challenging sources of enzyme inhibitors for pharmacological applications. Mar Drugs 15:173. https:// doi.org/10.3390/md15060173

Sadahiro Y, Hitora Y, Fukumoto A, Ise Y, Angkouw ED, Mangindaan REP, Tsukamoto S (2020) Melophluosides A and B, new triterpene galactosides from the marine sponge Melophlus sarasinorum. Tetrahedron Lett 61:1-13. https://doi.org/10.1016/j.tetlet. 2020.151852

Samoylenko V, Khan SI, Jacoba MR, Tekwani BL, Walker LA, Hufford CD, Muhammad I (2009) Bioactive (+)-manzamine A and (+)-8-hydroxymanzamine: A tertiary bases and salts from Acanthostrongylophora ingens and their preparations. Nat Prod Commun 4:185-192

Screen M, Britton M, Downey SL, Verdoes M, Voges MJ, Blom AEM, Geurink PP, Risseeuw MDP, Florea BI, van der Linden WA, Pletnev AA, Overkleeft HS, Kisselev AF (2010) Nature of pharmacophore influences active site specificity of proteasome inhibitors. J Biol Chem 285:40125-40134. https://doi.org/10.1016/j. cbpa.2014.08.012

Shady NH, Elfakharany Z, Salem MA, Ahmed S, Fouad MA, Kamel MS, Krischke M, Mueller MJ, Abdelmohsen UR (2020) Dereplication analysis and antitrypanosomal potential of the red sea sponge Amphimedon sp. supported by molecular modelling. Rev Bras Farmacogn 30:290-294. https://doi.org/10.1007/ s43450-020-00053-1

Shen Q, Wang J, Liu CX, Cui W, Zhang L, Zhang Y, Wang Y, Wu J, Li JX (2019) Synthesis and evaluation of tetrahydroquinolin$2(1 H)$-one derivatives as novel anti-pancreatic cancer agents via targeting autophagy. Eur J Med Chem 170:28-44. https://doi.org/ 10.1016/j.ejmech.2019.03.013

Shi Z, Tabassum S, Jiang W, Zhang J, Mathur S, Wu J, Shi Y (2007) Identification of a potent inhibitor of human dual-specific phosphatase, VHR, from computer-aided and NMR-based screening to cellular effects. ChemBioChem 8:2092-2099. https://doi.org/ 10.1002/cbic. 200700397

Shrestha S, Sorolla A, Fromont J, Blancafort P, Flematti GR (2018) Crambescidin 800, isolated from the marine sponge Monanchora viridis, induces cell cycle arrest and apoptosis in triple-negative breast cancer cells. Mar Drugs 16:53. https://doi.org/10.3390/ md16020053

Swantara MD, Rita WS, Suartha N, Agustina KK (2019) Anticancer activities of toxic isolate of Xestospongia testudinaria sponge. Vet World 12:1434-1440. https://doi.org/10.14202/vetworld. 2019.1434-1440

Tandon R, Singh I, Luxami V, Tandon N, Paul K (2019) Recent advances and developments of in vitro evaluation of heterocyclic moieties on cancer cell lines. Chem Rec 19:362-393. https://doi. org/10.1002/tcr.201800024

Tanokashira N, Kukita S, Kato H, Nehira T, Angkouw ED, Mangindaan REP, de Voogd NJ, Tsukamoto S (2016) Petroquinones: trimeric and dimeric xestoquinone derivatives isolated from the marine sponge Petrosia alfiani. Tetrahedron 72:5530-5540. https://doi.org/10.1016/j.tet.2016.07.045

Tarazona G, Santamaría G, Cruz PG, Fernández R, Pérez M, MartínezLeal JF, Rodríguez J, Jiménez C, Cuevas C (2017) Cytotoxic anomoian B and aplyzanzine B, new Bromotyrosine Alkaloids from Indonesian Sponges. ACS Omega 2:3494-3501. https://doi. org/10.1021/acsomega.7b00417

Taylor MW, Radax R, Steger D, Wagner M (2007) Sponge-associated microorganisms: evolution, ecology, and biotechnological potential. Microbiol Mol Biol Rev 71:295-347. https://doi.org/ 10.1128/MMBR.00040-06

Tuccinardi T, Granchi C, Iegre J, Paterni I, Bertini S, MacChia M, Martinelli A, Qian Y, Chen X, Minutolo F (2013) Oxime-based inhibitors of glucose transporter 1 displaying antiproliferative effects in cancer cells. Bioorg Med Chem Lett 23:6923-6927. https://doi.org/10.1016/j.bmcl.2013.09.037

Urda C, Fernández R, Rodríguez J, Pérez M, Jiménez C, Cuevas C (2017) Daedophamide, a cytotoxic cyclodepsipeptide from a Daedalopelta sp. sponge collected in Indonesia. J Nat Prod 80:3054-3059. https://doi.org/10.1021/acs.jnatprod.7b00678

Usui T, Kojima S, Kidokoro SI, Ueda K, Osada H, Sodeoka M (2001) Design and synthesis of a dimeric derivative of RK-682 with increased inhibitory activity against VHR, a dual-specificity ERK phosphatase: Implications for the molecular mechanism of the inhibition. Cell Chem Biol 8:1209-1220. https://doi.org/10. 1016/S1074-5521(01)00089-8

Wang J, Bourguet-Kondracki ML, Longeon A, Dubois J, Valentin A, Copp BR (2011) Chemical and biological explorations of the electrophilic reactivity of the bioactive marine natural product halenaquinone with biomimetic nucleophiles. Bioorg Med Chem Lett 21:1261-1264. https://doi.org/10.1016/j.bmcl.2010. 12.056

Wang W, Qin J, Voruganti S, Nijampatnam B, Velu SE, Ruan K, Hu M, Zhou J, Zhang R (2018) Discovery and characterization of dual inhibitors of MDM2 and NFAT1 for Pancreatic Cancer Therapy. Cancer Res 78:5656-5667. https://doi.org/10.1158/0008-5472. CAN-17-3939

Wang Z, Kang W, You Y, Pang J, Ren H, Suo Z, Liu H, Zheng Y (2019) USP7: novel drug target in cancer therapy. Front Pharmacol 10:1-15. https://doi.org/10.3389/fphar.2019.00427

Watts KR, Morinaka BI, Amagata T, Robinson SJ, Tenney K, Bray WM, Gassner NC, Lokey RS, Media J, Valeriote FA, Crews P (2011) Biostructural features of additional jasplakinolide (jaspamide) analogues. J Nat Prod 74:341-351. https://doi.org/10. $1021 / \mathrm{np} 100721 \mathrm{~g}$

Wilcken R, Zimmermann MO, Lange A, Joerger AC, Boeckler FM (2013) Principles and applications of halogen bonding in medicinal chemistry and chemical biology. J Med Chem 56:1363-1388. https://doi.org/10.1021/jm3012068

Wojcieszak J, Andrzejczak D, Kedzierska M, Milowska K, Zawilska JB (2018) Cytotoxicity of $\alpha$-pyrrolidinophenones: an impact of $\alpha$-aliphatic side-chain length and changes in the plasma membrane fluidity. Neurotox Res 34:613-626. https://doi.org/10. 1007/s12640-018-9923-1

Wu Q, Nay B, Yang M, Ni Y, Wang H, Yao L, Li X (2019) Marine sponges of the genus Stelletta as promising drug sources: chemical and biological aspects. Acta Pharm Sin B 9:237-257. https:// doi.org/10.1016/j.apsb.2018.10.003

Wu C, Cheng Z, Lu D, Liu K, Cheng Y, Wang P, Zhou Y, Li M, Shao X, Li H, Su W, Fang L (2021) Novel $N$-methylated cyclodepsipeptide prodrugs for targeted cancer therapy. J Med Chem 64:991-1000. https://doi.org/10.1021/acs.jmedchem.0c01387

Xie M, Liu D, Yang Y (2020) Anti-cancer peptides: classification, mechanism of action, reconstruction and modification: anticancer 
peptides. Open Biol 10:200004. https://doi.org/10.1098/rsob. 200004rsob200004

Xu Y, Zhang L, Wang Q, Zheng M (2020) Comparison of different colorectal cancer with liver metastases models using six colorectal cancer cell lines. Pathol Oncol Res 26:2177-2183. https:// doi.org/10.1007/s12253-020-00805-3

Yamada M, Takahashi Y, Kubota T, Fromont J, Ishiyama A, Otoguro K, Yamada H, Omura S, Kobayashi J (2009) Zamamidine C, 3,4-dihydro-6-hydroxy-10,11-epoxymanzamine A, and 3,4-dihydromanzamine $\mathrm{J} \mathrm{N}$-oxide, new manzamine alkaloids from sponge Amphimedon sp. Tetrahedron 65:2313-2317. https://doi.org/10. 1016/j.tet.2009.01.032

Yamazaki H, Ohte S, Rotinsulu H, Wewengkang DS, Sumilat DA, Abdjul DB, Maarisit W, Kapojos MM, Namikoshi M, Katagiri T, Tomoda H, Uchida R (2020) Screening for small molecule inhibitors of BMP-induced osteoblastic differentiation from Indonesian marine invertebrates. Mar Drugs 18:606. https://doi. org/10.3390/md18120606

Yeung TM, Gandhi SC, Wilding JL, Muschel R, Bodmer WF (2010) Cancer stem cells from colorectal cancer-derived cell lines. Proc Natl Acad Sci 107:3722-3727. https://doi.org/10.1073/pnas. 0915135107

Yousaf M, Hammond NL, Peng J, Wahyuono S, McIntosh KA, Charman WN, Mayer AMS, Hamann MT (2004) New manzamine alkaloids from an Indo-Pacific sponge. Pharmacokinetics, oral availability, and the significant activity of several manzamines against HIV-I, AIDS opportunistic infections, and inflammatory diseases. J Med Chem 47:3512-3517. https://doi.org/10.1021/ jm030475b
Yuan P, Xu B, Wang C, Zhang C, Sun M, Yuan L (2016) Ki-67 expression in luminal type breast cancer and its association with the clinicopathology of the cancer. Oncol Lett 11:2101-2105. https:// doi.org/10.3892/ol.2016.4199

Zhai M, Wang L, Liu S, Wang L, Yan P, Wang J, Zhang J, Guo H, Guan Q, Bao K, Wu Y, Zhang W (2018) Synthesis and biological evaluation of (1-aryl-1H-pyrazol-4-yl) (3,4,5-trimethoxyphenyl)methanone derivatives as tubulin inhibitors. Eur J Med Chem 156:137-147. https://doi.org/10.1016/j.ejmech. 2018.05.058

Zhang QT, Liu ZD, Wang Z, Wang T, Nan W, Ning W, Zhang B, Zhao YF (2021a) Recent advances in small peptides of marine origin in cancer therapy. Mar Drugs 19:115. https://doi.org/10.3390/ md19020115

Zhang W, Gou P, Dupret J-M, Chomienne C, Rodrigues-Lima F (2021b) Etoposide, an anticancer drug involved in therapyrelated secondary leukemia: enzymes at play. Transl Oncol 14:101169. https://doi.org/10.1016/j.tranon.2021.101169

Zhao B, Zhao C, Hu X, Xu S, Lan Z, Guo Y, Yang Z, Zhu W, Zheng P (2020) Design, synthesis, and 3D-QSAR analysis of novel thiopyranopyrimidine derivatives as potential antitumor agents inhibiting A549 and Hela cancer cells. Eur J Med Chem 185:111809. https://doi.org/10.1016/j.ejmech. 2019.111809 